Portland State University

PDXScholar

7-1997

\title{
Law Enforcement Attitudes toward the 1989 Oregon Firearms Law and Gun Control
}

Andrew Schneiderman

Portland State University

Follow this and additional works at: https://pdxscholar.library.pdx.edu/open_access_etds

Part of the Politics and Social Change Commons

Let us know how access to this document benefits you.

\section{Recommended Citation}

Schneiderman, Andrew, "Law Enforcement Attitudes toward the 1989 Oregon Firearms Law and Gun Control" (1997). Dissertations and Theses. Paper 5487.

https://doi.org/10.15760/etd.7350

This Thesis is brought to you for free and open access. It has been accepted for inclusion in Dissertations and Theses by an authorized administrator of PDXScholar. Please contact us if we can make this document more accessible: pdxscholar@pdx.edu. 


\section{THESIS APPROVAL}

The abstract and thesis of Andrew Schneiderman for the Master of Science in Administration of Justice were presented on May 21st, 1997, and accepted by the thesis committee and the department.

COMMITTEE APPROVALS:

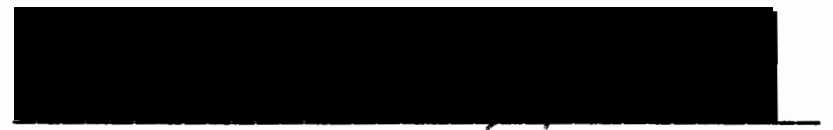

Charles Tracy, Chair

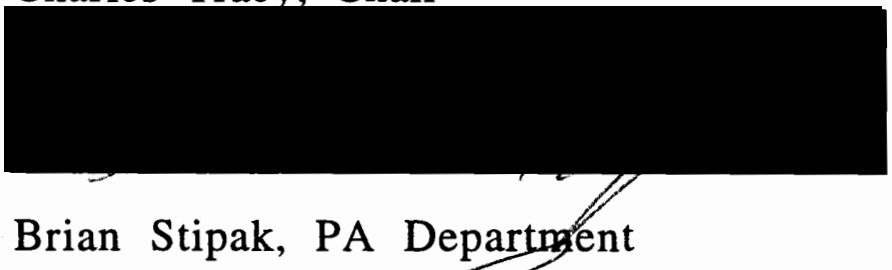

DEPARTMENT APPOVAL:

Gary Perlsteln, Chair

Gary Perlstein, AJ Department

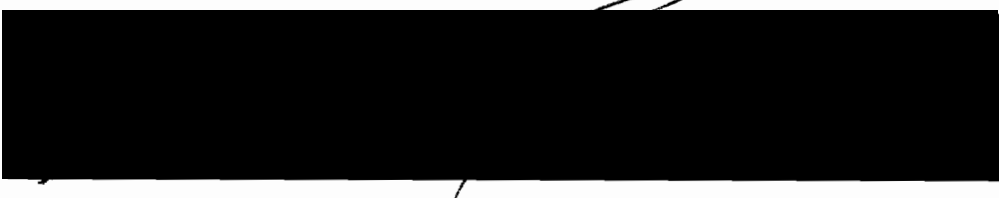

Department: Administration of Justice

\section{ACCEPTED FOR PORTLAND STATE UNIVERSITY BY THE LIBRARY}

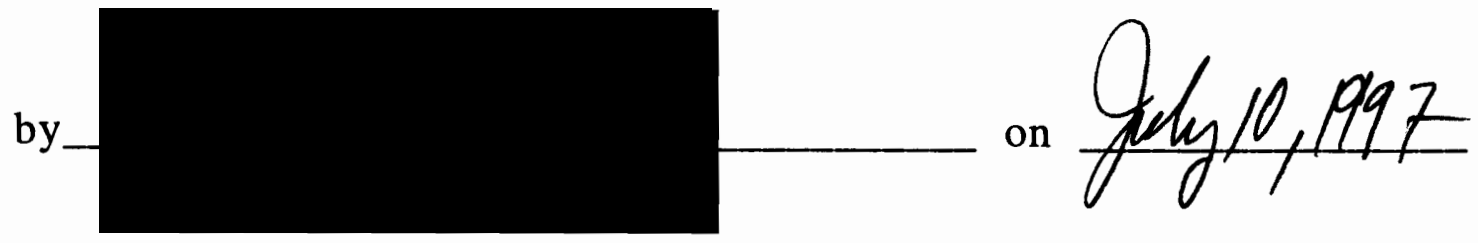




\section{ABSTRACT}

An abstract of the thesis of Andrew Schneiderman for the Master of Science in Administration of Justice presented May 13th, 1997.

Title: Law Enforcement Attitudes toward the 1989 Oregon Firearms Law and Gun Control.

The US Supreme Court decision Deshaney v. Winnebago County Department of Social Services cited; "the police or other government agents are under 'no general duty' to provide services, such as protection, to any particular citizen. But rather, duty to provide public services owed only to the public at large, and absent special relationships between police and individuals"(109 S.Ct. 998/1989). At the same time of this decision, the public was undergoing a trend of proliferating millions of personally owned firearms for self-defense and sport. In addition, citizens are now carrying concealed handguns in the 31 states that allow such a behavior.

Oregon in 1989 became one of the latter states by revising its firearm laws; Oregon enacted a "shall issue" permit system regarding the issuing of Concealed Handgun Licenses. With more citizens (Multnomah County Sherrif's office, approximately 
$85,000)$ carrying concealed handguns, safety becomes an issue. The safety of individual police officers and the public at large, versus the rights under Oregon's Constitution (Article 1, Section $27 " .$. to keep and bear arms for the defense of themselves and the state shall not be infringed..."), becomes the conflict for those involved.

The purpose of the present study is to present the argument that if the rank and file police officer is not liable to protect the citizen, he/she is supportive of concealed carry permits for handguns. To address the aforementioned issue, the present researcher will answer the following questions: Why are the police not protecting us against crime? Are the police liable to protect the individual citizen from the criminal element? Are police officers comfortable knowing average law-abiding citizens are carrying concealed handguns? Do police support this premise?

With these attitudes uncovered, proper policy for citizenpolice encounters involving those legally carrying concealed handguns can be developed. To address the aforementioned issues, a standardized quesionaire should be used. 246 certified BPSST Oregon Police Officers were purposively sampled from 6 Oregon Municipal Police Departments. The agencies included Salem, Or. PD; Medford, Or. PD; Astoria, Or. PD; Bend, Or. PD; Porland, Or. PD; and Washington County Sherrif's Office. 
LAW ENFORCEMENT ATTITUDES TOWARD

THE 1989 OREGON FIREARMS LAW AND

GUN CONTROL

b y

ANDREW SCHNEIDERMAN

A thesis submitted in partial fulfillment of the requirements for the degree of

\author{
MASTER OF SCIENCE \\ in \\ ADMINISTRATION OF JUSTICE
}

Portland State University

1997 
TABLE OF CONTENTS

LIST OF FIGURES

SECTION 1: INTRODUCTION

SECTION 2: STATEMENT OF THE PROBLEM

APPENDIX: (A) QUESTIONAIRE

(B) CONSENT FORM

(C) PUBLIC ORDER OFFENSES 


\section{LIST OF FIGURES}

\section{Figure \#1}

Differences between younger and older officers on safety training.

\section{Figure \#2}

Differences between younger and older officers on concealed carry permits.

\section{Figure \#3}

Differences between younger and older officers regarding licensing handguns.

\section{Figure \#4}

Differences between younger and older officers regarding registrating handguns.

Figure \#5

Differences between younger and older officers regarding police involvment.

Figure \#6

Differences between firearm owners and non-owners on licensing handguns.

Figure \#7

Differences between firearm owners and non-owners on registrating handguns.

Figure \#8

Differences between firearm owners and non-owners on prohibition.

Figure \#9

Differences between males and females toward concealed carry permits.

Figure \#10

Differences between males and females regarding the licensing of handguns. 


\section{LIST OF FIGURES (cont.)}

\section{Figure \#11}

Differences between males and females regarding the registration of handguns.

Figure \#12

Should police be involved in the training of citizens who want to carry handguns?

Figure \#13

Officers who've faced deadly force and their opinion on concealed carry permits.

Figure \#14

Officers who've faced deadly force and their opinion on licensing handguns.

Figure \#15

Officers who've faced deadly force and their opinion on registrating handguns. 


\section{INTRODUCTION}

In 1995, the violent crime rate in the United States has been consistently high compared to other European and Asian countries. In fact, for every 1000 people there was 1.6 rape victims, 5.3 robbery victims for every 1000 people, and 37.6 assault victims for every 1000 people (NCVS, Nasser, 1997). Unfortunately, there has even been 70 people murdered a day in the United States (Oregonian, 2/2/95). When compared to two years earlier, the 1993 Uniform Crime Report/National Crime Victimization Survey (NCVS) shows similiar trends citing a man or women is violently assaulted every 17 seconds, a woman raped every 2.5 minutes, and a person is murdered every 21 minutes. In fact, the Justice Department cites that at some point in our lives $83 \%$ of Americans will be effected by violent crime (Seligman, 1993, p. 141). With the fear of crime escalating and the reporting of it through the local TV and Newspaper media, the public at large is deeply concerned. Legislation calling for mandatory sentencing guidelines, more police, more prisons, the death penalty and even restrictions on handgun ownership have surfaced in Congress and in specific states.

Yet on April 14, 1997, the USA TODAY newspaper reported the headline that read "Violent Crime down 12.4\%". The article cites Justice Department statistics that show violent crime in the US has fallen $12.4 \%$ in 1995 from 1994. Rape, robbery, assault, theft, and household burglary dropped from 42.3 million crimes to 
38.4 million crimes (Nasser, 1997). Even amongst racial divides, crime is down with crimes against whites down $12.8 \%$ and crimes against blacks down $10.4 \%$. Even with this slight drop in crime, one must realize that crime is still the number one topic in American politics. Unfortunatety, the prejudice about the statistics cited by the author like the fact that only crimes reported to the police are counted cannot be discounted. Most researchers including the present researcher will agree that there is a weakness about official statistics. In addition, the author tries to make some investigative assessments of why crime has fallen and comes up with several theories. One is the aging of the baby boomer generation that has reduced the population of those individuals capable of committing crime (aging out). On the other hand, the author claims that the boom let generation is on the rise which may reverse this trend. "A lot more of the violence is perpetrated by juveniles," says Susan Howley with the National Victim Center in Arlington, Virginia (Nasser, 1997, p. 4A). The New York times reported that homocide rates amongst 24 or younger have exploded. Among those aged 14 to 17 , in fact, the rate has tripled to 18.6 per 100,000 in 1993 from 6.2 per 100,000 in 1984 (Butterfield, (1995). Lastly, another factor for the decline of crime is the tough on crime solutions like tougher sentencing laws or the new "Community Policing" strategy (Nasser, 1997).

Yet, Goleman (1994) on the other hand states "News coverage is a major importance in people's reaction to a risk: The 
more attention the news media pay to it, the worse it is assumed to be". Can one say that as the media addresses crime more often on the evening news, the response will be fear? This scenario is true for the public has invested millions into the Alarm, Martial Arts, and Firearm industries which are at an all time high (Congressional Quarterly Weekly, 1993).

Ironically, according to Goleman (1994) more people are more likely to be injured or fatally injured in miscellaneous accidents than by violent crime. People are still more likely to be injured or killed in a motor vehicle accident, by smoking, by falling, or drowning than to be murdered, raped or robbed (abid.). Firearm accidents are 5 th on the list of leading causes of death trailing heart disease, cancers, strokes, motor vehicle accidents, falls ect....(NCHS, 1995). Nonetheless, if crime is going down why do polls and fears of crime keep going up. With this fear of crime going up and overall crime rates stabilizing or declining, the present researcher hopes to address the following issues: How has the public responded to this fear of crime? Why aren't the police doing anything about crime? Why are the police not protecting us? Lastly, are the police liable to protect the individual citizen from the criminal element?

People in Oregon have been addressing the fear of crime similar to national trends by buying alarms, taking martial arts classes and even buying firearms. As early as 1981, there has been a proliferation of handguns in the United States amongst its 
citizens to combat crime (Norman and McAninch,1983). The previous researcher uncovered that approximately 55 million handguns were in circulation in the US at that time. However, today the Justice Department and the NRA have inflated that figure to about $80+$ million handguns not including rifles and shotguns (NRA Firearms Fact Book,1995). The total figure of firearms in circulation at the present is approximately 200 million+. The National Rifle Association claims to date that over 250 million firearms exist in the United States. NRA claims that one out of every 2 homes contains a firearm.

In response to the fear of crime and the proliferation of firearms, the legislators of several states including Oregon began to address the issues of citizen's rights vs. public safety. With more people buying firearms, is the public safety at risk? Several politicians had even feared a return to the wild west days with standoff shoot-outs. Florida was the first state in 1987 to address the issue of children's access to firearms following several accidents involving firearms and children (The Washington Post June 22 1989). Adults were now liable for their children's access to those firearms and any negligent deaths that occurred. In addition, Florida enacted a concealed carry of a handgun permit system. Citizens once qualified according to a background investigation and a safety course could carry a concealed handgun (Hammer, 1995). To date 221,443 licenses have been issued between Oct. 1987 and April 1994 (Lott and Mustard (1996). 
Virginia in 1988 addressed the issue of easily identifying criminals before they take possession of firearms. Instant background checks were performed at the time of sale without denying legal owners the same channels.

Oregon in 1996 passed legislation similar to Florida involving the issue of liability for firearm accidents involving children (Oregonian, 1996). Oregon initially revised its firearm laws in 1989 legislating similar laws as Florida dening access to firearms by suicidal and homicidal persons (Canby,1990, p.568). Arizona in July 1994 also became a shall issue state by allowing more than 35,000 citizens to obtain concealed carry permits (Nichols and Kelly, 1996). Texas is the most recent example of states that allow concealed carry permits for citizens. Since the law took place on Jan. 1, 1996, there has been 500,000 requests for applications. At the time the article was written, there had been 16,000 permits issued (Statesman Journal, 1996). To date, more than 31 states have established a concealed carry permit system. They vary from a "...only to and from ..." (the gun range only) system in the state of New York, to the limited restrictions of the concealed permit system of Oregon outlawing carrying in Federal Buildings, Airports, and Schools (Crimes and Punishments, 166.293). 


\section{STATEMENT OF PROBLEM}

With more citizens-approximately 85,000 determined by Multanomah County Sheriff's Office/1996-carrying concealed handguns, public safety becomes an issue. The safety of individual police officers and the public at large, versus the rights under Oregon's Constitution Article 1, Section 27 stating, "The people shall have the right to bear arms for the defense <sic> of themselves, and the State, but the Military shall be kept in strict subordination to the civil power" (Constitution of Oregon p.1002), becomes the conflict for those involved. With the present research, the present researcher hopes to answer the following questions: Should citizens seeking to legally carry handguns for the defense of themselves and their families be allowed to do so? Do police support this premise? One of the main problems with this growing trend in firearm proliferation is the question of police protection. The all familiar mantra "To Protect and to Serve" has convinced millions of Americans including myself that the police have a duty to protect the individual. However, the legal status of that argument is quite the opposite.

The US Supreme Court decision Deshaney v. Winnebago County Department of Social Services cites; "the police or other government agents are under 'no general duty' to provide services, such as protection, to any particular citizen. But rather, duty to provide public services owed only to the public at large, and absent special relationships between police and individuals"(109 
S.Ct. 998/1989). This precedent case involved a domestic abuse case which according to the United States Supreme Court declared, police are not liable to protect individual citizens unless under special relationships. These special relationships are few. For example, incarcerated prisoners whose' liberty is limited fall under the special duty doctrine. Second, the mentally ill who are also limited in movement and restrained against their will fall under this doctrine. Thirdly, arrestees who are in the process of being taken into custody need protection (Schofield, 1991, p.27). Lastly, when police need assistance from an individual citizen in making an arrest, that individual is charged by the police officer to assist but owed a special relationship doctrine and protection (Schuster v. City of New York).

Below is a brief history of cases from state supreme courts which also show consistency with the aforementioned ruling. The Iowa State Supreme court in 1992 ruled on a case involving the Urbandale Police Department. The case involved a threat to a Victory Graham by her former boyfriend Harvey Spencer. The Officer who took the initial call about the threat promised a "special extra watch" involving a additional patrol car periodically patrolling by her home. Another officer at the same time looked for the boyfriend elsewhere which failed. Without keeping up on the promise to the woman, the boyfriend returned and shot the woman. The Plaintiff claimed in court that a special relationship existed due to the Officer's promise. The Court ruled that while the 
woman may have been lulled into a false sense of security by the promise, she failed to take reasonable measures for her own safety. "In addition, the public is better served by a policy that encourages police to provide additional protection without the fear of being held liable for mistakes" (Police Liability Review, Spring $1993 \mathrm{p} 28)$.

The Missouri State Supreme Court ruled on a case in 1992 on similar grounds of Deshaney. The Plaintiffs in this case were bringing civil liability suits against the Kansas City Police Department and the Kansas City Board of Police Commissioners. The Plaintiffs contend that a man sexually molested their young daughter Jessica Taylor due to the failure of the department in providing adequate protection. The first theory for the existence of a special relationship involved the identification of a male-last name-Moore by one Detective before the molestation. When the detective was made aware of the intent to do harm to Jessica, an arrest was not speedily expedited which caused the molestation to occur. Second, the Taylor parents contend that they notified the police about the threat and were given "blanket assurances" about protection creating a special relationship. Lastly, with the detective notifying Moore about his investigation, a true threat developed against the plaintiff placing her in danger and did create a special relationship. The court ruled that it is the duty owed the public by the police of assuring them of protection in times of emotional crisis. The nature of police work is to calm the public's fears. If a 
special relationship existed every time an officer made blanket protection assurances, " the exception would swallow the rule". Therefore, the court ruled that the plaintiffs failed to provide that a special relationship existed and that the defendants breached that duty (Police Liability Review, Spring 1993, p23).

In 1991, the Ohio State Supreme Court ruled on a case involving kidnapping and an alleged special relationship owed Karen Siddle by the police. Karen Siddle at the time the incident occurred left her abusive husband James Siddle in Cambridge, Ohio. Mr. Siddle on numerous occasions followed her and insisted on wanting to speak to Karen. On one occasion James Siddle broke a window at the location where Karen was staying to gain entry and then abducted her. The Guernsey County Sheriff's Department was notified. The Cambridge City Police Department was also notified about the abduction within a week. No arrest of Mr. Siddle was made. Karen left her former location and moved into a shelter for battered woman (Haven of Hope). Mr. Siddle was able to track her down again and began to stalk her. Again, he managed to talk her into meeting him and abducted her. Karen filed a restraining order against James Siddle which served no purpose for Karen was abducted several more times. James was even arrested on one occasion and assured police that he would leave her alone. What is interesting is that Karen after all these abductions was not harmed. Inaddition, she did not file charges toward James Siddle. The suit filed against Cambridge City, Ohio PD was based on the 
restraining order filed by Karen. The court ruled that even though a restraining order created a special relationship and a duty to protect Karen (an individual) by the police, the duty was one of reasonable protection (Police Liability Review, Spring 1993 p20). Karen therefore needed to take precautions for her own safety. In the case of Willard vs. Everton ruled by the Supreme Court of Florida in 1983, a special duty to protect did not exist. While this case involved a drunken driver, the precedent for no duty to protect citizens still remains. The case involved Marion Willard who was stopped by a Pinellas County Sheriff's deputy for a traffic violation. Upon interviewing Willard, the deputy noticed that Willard had been drinking which Willard then even admitted drinking. The deputy did not arrest Willard for DWI but cited and released. 15 minutes later Willard was involved in a traffic accident which led to the death of another motorist and the injury of another. The plaintiffs brought suit against the Deputy and the County for failing to provide the public and the individual motorist protection from the intoxicated motorist.

While the court agreed with the legislative statutes concerning intoxicated persons being a menace to the road, the court found that the police were not liable. The court ruled that the issue filed by the plaintiffs in this case was an issue of discretion by the law enforcement deputy in making an arrest or not. The court affirmed that governmental decisions or judgments in enforcing the law is a power authorized to law enforcement. 
Therefore, the deputy being a representative of that government is charged with basic discretionary, judgmental decisions which are inherent in enforcing the law based on reasonableness. Therefore, these authorized decision making powers are immune from tort liability (468 Southern Reporter, 2d Series, p936).

Another case in the District of Columbia in 1981 also affirmed that police are under no duty to protect an individual citizen, but rather, a duty to provide public service owned only to the public at large. 3 women were asleep in their 3 story home in the District of Columbia. The three were awakened by the sound of a door being broken down on the groung floor and the sounds of individuals roaming downstairs. Kent and Morse (perpetrators) had broken their way into the home. Two of the women who lived on the third floor heard the screams of Douglas (one resident) who lived on the second floor. One woman, Warren phoned the police to complain of a burglary in progress and requested immediate assistance. The call was dispatched at $6: 26$ am as a Code 2 response.

The police responded with one patrol car patrolling an alley adjacent to the house, one officer knocking at the front door getting no response and failing to enter the house, another car was dispatched to locate a suspect at another location, and the last officer who never even left his vehicle. The police then drove off as a Code 4 incident at 6:33 am. However, the men were still inside the home. The two women who had crawled onto the roof while 
the perpetrators were inside the house crawled inside to again hear the screams of Douglas from the second floor. They then called the police a second time to ask for immediate assistance. 911 received the call at 6:42am and never dispatched an officer to the scene. Later, certain sounds heard downstairs by the women on the third floor raised suspicion that police had finally entered the house. Therefore, the two women upstairs called to Douglas downstairs alerting the two intruders to their presence. All three women were then forced to Kent's apartment where they were sexually assaulted, raped, robbed, beaten, and forced to commit lesbian acts upon each other.

In court the plaintiffs suit cited that the dispatch was negligent for failing to issue the proper Code 1 response instead of the Code 2 response. The dispatch was also accused of failing to dispatch any units to the $6: 42 \mathrm{am}$ call. The plaintiffs also cite that the police who responded failed to use standard police procedures in positioning themselves by the entrances and exists of the home, failed to remain for a longer period of time, and failed to enter the house. While it may seem reasonable that the police were liable to protect these individuals, the duty is still only to the public at large according to the Florida Supreme Court. The court stated that a maintained police force constitutes a basic governmental service providing a benefit to the community at large. By referring to other court decisions, the Florida Supreme Court affirmed Deshaney by stating that the police services established by a 
municipality owe a service only to the public at large and not to individual citizens of that community (444 Atlantic Reporter, 2d. Series, p.2). Therefore, the women failed to take precautionary measures for their own safety.

As a last example, The New York State Court of Appeals overruled a lower case ruling in 1982 of a New York City suit against the New York City Transit Authority. The plaintiff Weiner entered a 25th street New York City subway entrance at about 12:15am on December 4, 1973. Since there was no change booth attendants at this entrance, the plaintiff had to use the 23rd street entrance where there was an attendant. A man suddenly blocked her way on the steps and attempted to cut her purse strap but at the same time slashing her wrist. This is not the first time this kind of robbery and assault with a deadly weapon occurred at this station. 13 other incidents were reported to the Transit Police occurring in the last 10 months within this location. Weiner, the last victim filed suit that the Transit Authority acting as any "common carrier" was liable to protect it's passengers as any airline or bus service.

The Court of Appeals affirmed the Transit Authorities claim that it performs a governmental function and is not under any duty to provide police protection than is any other municipality. In addition, the claim that the NY Transit Authority acts as a common carrier is not sufficient evidence for liability. Therefore, in order to provide that protection owed a individual, the plaintiff must show 
a special relationship for which the plaintiff failed to do. Lastly, the court also held that the allocation of police resources in deterring or preventing criminal activity is a legislative-executive decision for which there is no liability (433 North Eastern Reporter, 2d Series).

One could see that in order for a police department to consider a special relationship to exist, one must fall into the following criteria: an individual must be in custody, incarcerated, or assisting the police. One could also see why many people are beginning to consider owning firearms. In most of the aforementioned cases especially the burglary, robbery and even the sexual assault incidents, the ownership of a firearm might have deterred the crime. The big question is whether firearm ownership is effective in deterring criminal activity. There is no absolute data on the deterrence of firearm ownership. However, several past and present studies are revealing more information that could be used to justify an armed response to crime.

Gary Kleck in 1991 wrote Guns and Violence: A Summary in the field in which he wrote about firearms used in crime and firearms as a deterrent to crime. He cites government statistics in total for the year 1985 in which firearms were used in murders, robberies, rapes, injuries, suicides and defense. The total number of firearm crimes for the year1985 is about 650,000 (Kleck, Ch.1, 1991). He then objectively establishes the arguments for and against future gun control but tends to support the latter. His 
argument against gun control is that even with future legislation or even future prohibition, there exists $200+$ million firearms in the United States. Since confiscation is not a reasonable option, the existing stock would supply criminals for decades to come. In addition, each year about 1500-2000 criminals are killed with a firearm and 600 thousand to a million crimes are prevented each year involving a firearm (Kleck, Ch. 4,1991). Since half of all households contain a firearm and a third of them are for defensive use, access to these firearms will eventually be used to deter a criminal.

Kleck (1991) later argues that definitive numbers on the deterrent issue will never surface for of a fear of prosecution. Numerous states like New York have a so-called "Duty to Retreat", including within ones home. Therefore, those that do utilize firearms for self-defense are unlikely to report the incident to the police for they feel fearful of being arrested. In addition, some incidents utilizing a firearm as defense are categorized as a crime by police and not as a defense. To investigate the theory of armed defense, the studies of Wright, Rossi and Daly (1983) involved surveying convicted incarcerated criminals which does show support for the deterrence theory. According to Wright et al. (1983), 36\% of burglars and robbers were more likely to be fearful of entering a household if they believed the resident was armed. The National Institute of Justice Publications in1991 printed a survey of 835 hardened prison inmates who were asked if an 
armed citizen would deter them from committing a crime. More than $50 \%$ would not have committed a crime had they known the victim was armed or the dwelling in which the owner lived was armed (Sheley,1994:1-3). Lastly, in those states that allowed the carrying of firearms, rapists and robber's were also less likely to attack a potential victim if it was suspected that the victim was armed (Lott,1996). Kleck (1991) feels that armed resistance is as common as arrests involving burglars and robberies. He feels that widespread firearm ownership might lower crime rates over all. Another example of the effectiveness of firearm ownership in deterring crime is a paper written by John Lott and David Mustard (1996). Their support for firearm proliferation involved a time series study (1977-1992) of states that allowed concealed carry permits to be issued and individuals who acquired them. Their conclusions were that allowing individuals to carry concealed handguns deters crimes. Lott et al. averaged that states that did adopt concealed carry laws saw 1,570 fewer murders, 4,177 fewer rapes, and 60,000 fewer aggravated assaults than states that kept restrictive firearm ownership laws (Lott et al., Ch.3, 1996) (Lee,1996). In fact, the researchers utilized NCVS data which shows every year there is 80,000 defensive incidents involving firearms during assaults, robberies, and household burglaries. Lastly, the researchers claim that in those states that had carry permits, murders fell $8.5 \%$ and rapes and aggravated assaults fell 5 to $7 \%$ (Ch. 4,1996$)$. 
The latest example of studies to show a deterrent factor in the ownership of a firearm was done by (Kleck and Gertz, 1995p. 153, 180, and 182-4). Kleck's newest research shows that firearms are utilized in a self-defensive role up to 2 and a half million times a year, where 400,000 of these defenders believe that using the gun saved a life (Kleck et al.,1995). One could speculate that even if only $10 \%$ of these incidents truly occurred, 200,000 times a year a firearm is used in a defensive mode. Do events like the above happen in Oregon, today?

One example involved a North Portland Oregon woman who shot a man she found inside her house. This incident could be related to the Warren et al. case in the District of Columbia. Elaine Mariko Wingren arriving in her driveway noticed a man in her living home. Wingren who has a CCW (Concealed Carry of a Weapon Permit) approached the house. The man subsequently, climbed out a basement window and started to approach her. She told the man to stop his approach. When he failed to do so, Elaine fired the handgun she had been carrying. The man later died at the hospital. She later told police that she had several guns in the house and feared he had stolen them to use on other victims. The Multanomah County Grand Jury decided not to indict her (Maves Jr.,1994). How do police officers in general feel about idea of armed self-defense by the public? 


\section{LITERATURE REVIEW}

With the increase of carry permits being issued in the 31 states that now allow such issuance, are police officers comfortable knowing average law-abiding citizens are carrying concealed handguns? The International Association of Chiefs of Police (IACP), the Fraternal Order of Police Officers (FOP) and other high ranking Law Enforcement group representatives have shown a pro-gun control stance in the past. Some of the recent prominent examples of this pro-gun control stance have been displayed during the Brady Bill and Assault Weapon Ban debates in Congress. However, one must keep in mind that attitudes on gun control are as diverse as the United States population with it's $250+$ million inhabitants. The present study attempts to uncover trends that show support or opposition for gun control not conclusions.

One of the first research studies on this subject emerged in 1983 in the periodical Police Chief (Lester, 1983, p.7). Similar to the present research, an anonymous questionnaire was distributed to New Jersey police officers. The common issues that most of the municipal and state officers agreed upon was: strict controls of handgun sales, ban on the sale and manufacturing of so-called "Saturday Night Specials", the prohibition of citizens carrying handguns in their cars, tighter controls for dealers, and a waiting period to conduct a thorough criminal background check to be implemented before buyers take possession of a handgun. Lastly, 
both groups agreed on mandatory sentencing guidelines for those individuals who use a firearm in a crime.

However, both groups were less decisive over certain issues like the prohibition of handgun ownership except for police and authorized individuals (military and security). Second, another conflicting issue is whether public funds should be utilized to buy back firearms following a voluntary announcement was made. After confiscation the handguns would then be destroyed. Other issues like capital punishment were also addressed in relation to tighter handgun restrictions. The results found that the more likely an officer was in favor of tighter restrictions, the less likely officers favored capital punishment (ibid.).

In the Journal of Police Science and Administration, the present researcher found more information on the issue of law enforcement and gun control. Norman and McAninch (1983) sampled officers of the rank and file from two departments in Utah and Illinois. A majority of the officers were white, male, over 30 and acquired more than 9 years of experience. This sample is consistent with the present research. Questionnaires in selfaddressed stamped envelopes were distributed to these officers to measure a variety of gun control related issues including: gun laws and there deterrence toward crime, gun laws and deterrence against proliferation of illegally acquired handguns, prohibition of citizen handgun ownership, waiting periods, registration, background investigations for buyers, safety courses, ect... 
With regards to issues of restrictions before a citizen can take possession of a handgun, both Utah and Illinois officers agreed on the following subjects: both favored background investigations of all citizens purchasing handguns. Second, both groups favored waiting periods between the time a sale takes place and the time the owner takes possession of the handgun. Lastly, both groups agreed with the premise of mandatory training either sponsored by the NRA or other firearm safety instructors (Norman et al.,1983). With regards to present gun laws and their effect on criminal behavior, both groups disagreed that present laws prevent criminals from obtaining handguns. Next, current laws don't deter criminals from utilizing handguns illegally. Both groups disagreed that present gun laws and there sanctions prevent the shooting of police officers. Lastly, Both Illinois and Utah officers disagreed with the total prohibition of handgun ownership amongst the citizens of the United States (abid.). The researchers concluded that it would be difficult to state that this sample is representative of all officers. The law enforcement community encompasses varying geographical areas with varying political, economical, and racial divides. These divides would make it almost impossible to gather a consensus of attitudes. However, the present researcher hopes to show consistencies with the varying research on certain issues.

More information uncovered by the present researcher on the issue of Police attitudes toward handgun ownership appeared 
in the Journal of Police Science and Administration in 1984.

Similar to the present research, 100 confidential officers were randomly selected from 6 states, asked questions about experience, demographics and attitudes toward gun control (Siwik and Blount, 1984). A majority of the officers were male, white, over 30, and had acquired over 7 years of experience. Attitudes toward gun-control reflect the hypothesis of the researcher who was trying to correlate attitudes toward gun control based on the officers proficiency of handing handguns and the tendency to own personal firearms other than duty issued firearms.

As is consistent with the research Criminal Justice Newsletter (1986), mentioned later, both owners and non owners agreed with the premise of waiting periods and the value of mandatory safety training for prospective owners. Next, both owners and non owners were in agreement on the elimination of the so-called "Saturday Night Special" (SNS). Another issue measured in Siwik et al. (1984) and measured in the present research is the issue of whether stronger handgun restrictions would remove handguns from the hands of criminals. In Siwik et al. (1984), both groupsowners and non owners-disagreed with this premise. Both groups believed that criminals will get firearms if they want them for they don't follow legal procedures and go through FFLs. Lastly, both groups rejected the idea of banning ownership of handguns among citizens which is consistent with Lester (1983). 
However, both owners and non owners were not always in consistent agreement. In regards to Siwik et al' (1984) hypothesis, it was summarized that the more officers owned a non-duty firearm for personal use, the more proficient the officer was in its use, the less likely the officer supported handgun restrictions on citizens. Second, in regards to licensing owners, those officers that owned firearms other than their duty weapon were less likely to favor licensing citizens. Another issue addressed in the present study is whether stronger handgun laws would reduce crime. A majority of officers in Siwik et al (1984) who owned several handguns disagreed that the law would reduce crime in comparison with non owners. While there was consistency in mutual support (owners and non owners) for issues like training, waiting periods, banning "SNS" and the enforcement of existing laws, issues like prohibition were less favored by both groups. The researchers hypothesis was supported by showing that the more an officer was proficient with a firearm, the more firearms he owned, the less likely he would favor strong controls (Siwik et al, 1984).

Another example of law enforcement attitudes on gun control surfaced in 1986 when the National Rifle Association introduced legislation called the Firearm Owners Protection Act. This legislation would weaken the interstate restrictions placed on sales by Federal Firearms Dealers and would allow more lawabiding citizens the ability to acquire firearms (Criminal Justice 
Newsletter, 1986, p.1). The Bill would also allow over the counter sales of handguns and longguns provided that those FFL dealers didn't violate state handgun laws. Immediately following the introduction of the bill, a coalition against the bill formed. Leading members of the FOP, IACP, National Sheriffs' Association, National Troopers Coalition, Federal Law Enforcement Officers Association, and the Police Foundation to name a few joined the opposition.

The new coalition charged that the new law would place more of a burden on the Criminal Justice System. Prosecutors would be harder pressed to prove the defendants' state of mind and conduct at the time of the crime. Second, the coalition stated that the defendants' lawyers would have an easier time beating current mandatory sentencing provisions by utilizing insanity pleas. Thirdly, law enforcement would have a harder time tracing firearms and would allow more to fall into the hands of criminals. Lastly, the coalition charged that this law would deny random inspections on FFLs, who according to Federal law need to keep records. The coalition charges that there would be an increase of illegal sales of firearms. These illegal sales due to decontrol according to the coalition would increase crime (Criminal Justice Newsletter, 1986).

One of the most prominent police departments active in the fight for gun control has been the Washington, DC. PD. Chief Assistant Isaac M. Fulwood stated that there needs to be consistent federal legislation on the sale and possession of handguns (Berg, 
1988). He feels that even though Washington, DC has one of the most strictest gun control laws in the nation which was implemented in 1976; (possession and sales of handguns are illegal) with the highest murder rates in the nation the criminal element has gone to those states where the laws are lax and acquires firearms them there. Fulwood states varying examples of states with lax laws like that of North Carolina and West Virginia where there is no background checks, to states with waiting periods like a 7 day waiting day period in Maryland, to allowing concealed carry permits in Florida to the prohibition in DC. He feels that until we have a national standard, the proliferation and illegal trafficking of handguns will continue (ibid.). To support this trafficking of firearms, the Alcohol Tobacco and Firearms and the Federal Bureau of Investigation have found numerous firearms turning up at crime scenes that were acquired illegally in other states.

More recent research to be found on the issue of law enforcement and their attitudes on gun control was to be found in the Police Chief $(1991$, p.6). The President of the organization addressed the debate over the Brady Bill. This piece of Federal legislation would mandate a 7 day waiting period between the time a handgun sale takes place and the time the owner takes possession of the handgun. This time period would require by federal mandate that the chief law enforcement agent of the area where the sale was to take place to do a background investigation 
on prospective buyers. Brown (1991) who wrote the article makes claims that we need this piece of federal legislation for our children and police officers are dying from handguns. Another claim by the author is that there is an inconsistency among the states with regards to handgun sale laws which allow criminals to go to those states where the laws are lax. While in those lax states, criminals can buy firearms with no criminal checks and transfer them across state lines to states where the laws are tight and sell them to other criminals.

The president also claims that the IACP and other law enforcement groups have supported this initiative ever since the failed attempt on President Reagan by John Hinkley. Brown (1991) finds it hard to believe that there is any controversy over a law designed to keep deadly weapons out of the hands of people with a criminal record or those that are mentally ill. Mr. Brown claims that the new law would not hamper or restrict law abiding citizens from obtaining handguns. This new law would merely verify biological and demographical information about the prospective buyer. Lastly, Lee Brown claims to be a leader of the law enforcement community along with others and wishes that their voices be heard in support of this law. One must ask how rank and file feel about the Brady Bill?

Also in "The Police Chief" (1994), the President of the organization at that time displayed his attitudes about another controversy issue namely the so-called "Assault Weapons Ban" bill 
(Daughtry Jr.1994). These weapons are similar in looks to there military counterparts. However, these weapons fire "semiautomatic" fire as opposed to "fully-automatic" fire. Semiautomatic firearms fire one round for every depress of the trigger. Fully-automatic firearms fire as many rounds in the magazine or feeding device for only one depress of the trigger. Regardless of the differences between these two types of firearms and the little statistics on these weapons used by criminals, the latter was associated with the former during the debate.

Mr. Daughtry Jr makes the prominent claim that while these weapons have there usage in wartime to kill as many people as possible with their high rate of fire, they have no place on the streets during peacetime. Mr. Daughtry Jr. has also claimed that this style of weapon has weakened the balance of power between police and the criminal element who possess them. In his own words he stated, "...it's time to ban assault weapons...", Daughtry Jr. (1994). What's interesting about this issue is the Justice Department and law enforcement agencies all over the country have proven that Assault Firearms rarely kill anyone (Library of Congress 1992). In addition, Mr. Daughtry claims the support of the IACP and all its members in their support of the passage of the Brady Bill and the Assault Weapons Ban. Next, he claims support from local chiefs in the states Oklahoma and Washington, police superintendents in the states Illinois and Massachusetts, the Chiefs of Police in Arkansas and others who have contacted and lobbied 
their respective representatives for their support of the ban. Finally, Mr. Daughtry met with President Clinton as leader of the IACP and it's members to support the ban (ibid.). One must ask once again how the IACP and FOP members feel about these pieces of legislation?

Up till now, the prominent attitudes toward gun control by the law enforcement community has been one of support. Law enforcement rank and file along with their high ranking officers have supported background checks, waiting periods, the Brady Bill, the Assault Weapons Ban, licensing and other restrictions placed on gun owners. However, one must ask if these opinions are the main stream or the public relation strategies developed by the law enforcement community in order to maintain their financing? The present researcher has found information to the contrary on the above issues.

The Law Enforcement Alliance of America organization and publication represents thousands of rank and file law enforcement officers who don't support gun control. One of the first examples of this trend of opposing attitudes toward gun control was written on the subject of gun buy back programs. City police departments like Portland, Or. (May 1997) would offer money, gift certificates and even toys for those individuals who turned in their firearms. These firearms would then by destroyed by furnace or smelter (Oregon Steel Works). 
The opinion of the author (Constance, 1994) of this article is that the buy back programs encourage criminals to steal. Most buy back programs have "no questions asked" policies on those individuals who surrender firearms. These policies according to the author encourage criminals to steal firearms to trade for money. Also, criminals can utilize firearms in criminal activities and then turn them in to be destroyed. "...We are promoting and participating in the destruction of evidence by providing criminals with a legal outlet for guns that have been used in the commission of violent crimes" (Constance, 1994, p.26). In fact, Mr. Constance acknowledges that the police are nothing more than a reactive agency. He feels that protection of the individual citizen rests with that individual citizen. This line of reasoning is consistent with the nature of the present researcher concerning concealed handguns. Lastly, Mr. Constance feels that any higher police administrator who supports these programs in the name of crime control is nothing more than a politician misleading the public into thinking a new crime fighting strategy has been invented (abid.). Attitudes like these are consistent with Lester (1983) where those officers who were sampled disfavored using public funds to buy back firearms.

From the same Spring 1994 issue of LEAA comes another article written by a FOP member. The author of this article analyzes the spiraling effect of gun-control legislation. He states, "I feel that once the legislature starts on gun control it will not quit 
until all guns and ammo are banned from sale" (Doran, 1994, p.40). He feels that future law will not stop there. Mr. Doran believes that there are so many fear mongering anti-gunners out there in the public and private realm, there will be a call for confiscation of existing firearms as in present day England and Australia. History has shown that confiscation of firearms from the citizenry has led to abusive police states (Germany, Russia, Cuba, China, Japan ect...). Lastly, Siwik et al. (1984), Norman et al. (1983), and Doran (1994) believe present gun laws will not prevent criminals from obtaining firearms. He states that the majority of firearms that he has come across were stolen, acquired through lying on applications or by false application.

Mr. Doran (1994) stated that law abiding citizens should be allowed to carry concealed firearms. He favors training citizens in handgun safety and in the legal consequences of using deadly force. With these safety measures in place according to Doran, the armed citizen can deter criminals. Any future legislation that makes it harder for law abiding citizens to carry firearms makes it easier for criminals to victimize innocent people and criminalizes those who are law abiding. Next, Mr. Doran feels that the existing laws on the books with regards to the use of firearms in a violent crime are sufficient. No new laws are necessary to curb crime. However, he does feel that they should be enforced to the maximum without parole or plea bargaining. Lastly, Mr. Doran feels that the Brady Bill will only hinder citizens from obtaining 
firearms when they feel they are in eminent threat of bodily harm (abid.).

The last article from the Spring 1994 issue of LEAA comes from another rank and file officer. One of the most interesting arguments that Mr. Jack Roberts (1994) makes is in regards to how criminals pick their prey. "As a police officer, it became immediately apparent to me that criminals only prey on defenseless individuals" (Roberts, 1994, p.45). Therefore, according to Mr. Robert's arguments if legislation is passed prohibiting citizens from owning firearms in comparison to criminals who don't obey the law the criminals will acquire them anyway; the criminals will certainly then prey on the law abiding. Mr. Robert's feels that responsible Americans should be allowed to carry firearms to protect their property, themselves, and their families. As stated in the United States Supreme Court decision Deshaney (1989), police can not guarantee the protection of the aforementioned. Lastly, a radical thought from the author of this article, he feels that the only way to eliminate the criminal is to become a police state. He does not agree with this premise though. Therefore, no one should disarm law abiding Americans and "place them in the hands at the mercy of murderers, rapists, and robbers (Robert's 1994).

The LEAA has a section in each quarterly issue that addresses gun control issues. A fact uncovered by the present researcher that is consistent with Deshaney (1989) is "The Myths 
of Police Protection" (Sutler, 1994, p.60). This argument relates to the present theme that citizens do not need firearms for they are protected by the police and the military. Once again the author makes the argument that (1) the police are a reactive agency that responds to calls from the public, (2) the police usually mop up the scene after the crime has already been committed and (3) there is enough legal precedent that determine that the police are not under any duty to protect the public. Sutler (1994) cites South V. Maryland 59 US (HOW) 396, 15 L. Ed., 433 (1856), Hartzler v. City of San Jose App., 120 Cal. Rptr. 5 (1975), and Warren v. District of Columbia, D.C. App., 444A. 2d. I(1981) ect...(abid p67).

To further support the need for an armed citizenry, the author points to the Los Angeles, California riots. During the LA riots, law abiding citizens, especially Koreans had to take up arms. They took up arms to protect their businesses from criminals, the Police and the National Guard during the looting. In addition, during Hurricane Andrew that devastated Florida and Dade County, citizens took up arms against the criminal element and the police who were looting. LEAA brings some balance into the argument of how law enforcement feels about gun control. However, the present author is only trying to bring both sides to the for front in order for the reader to render his own opinions. Today, attitudes of the law enforcement community vary as do those of the past concerning issues of gun control. One article was recently published in the National Rifle Associations' magazine 
titled American Rifleman. It addresses recent legislation that had been submitted to Congress which would limit handgun buyers to purchase only one handgun a month. This legislation reflects a bill that was signed into law in the state of Virginia to reduce gun trafficking to NY state and Washington DC. The article is titled "FOP to Oppose new Gun Control" (Teodorski, 1997). The author confirms that the National Vice President of the FOP, along with members of other law enforcement groups, will oppose this legislation. Mr. Teodorski states that after the passage of the Brady Bill and the Assault Weapons Ban, the FOP will not support any other gun control legislation of this kind (abid.). The columnist of the NRA responds that this attitude reflects that of the rank and file and it's about time.

The present researcher has mostly spoken about legislation that has effected citizens only. However, on September 30, 1996 Bill Clinton and Congress passed legislation prohibiting any citizen or POLICE OFFICER from owning a firearm if he/she has been convicted of domestic violence past or present (Nichols, 1997, p.1). Originally, in order for a person to be prohibited from owning a firearm, one would have to be convicted of a felony, be mentally incompetent, or be a drug addict. Now, citizens and police officers can be denied ownership for a misdemeanor. There is no exception or exemption for law enforcement or even the military. "How does this effect the 700,000 federal, state, and local law enforcement officers and 1.2 million Americans in the military..." (Nichols, p.1). 
The law requires all involved to surrender their firearms and ammo to authorities. One can imagine how the law enforcement community feels that their rank and file crime fighting, community servants must be reassigned to desk jobs. No longer can these individuals be effective on the streets. In addition, if there is no desk work available, those law enforcement officers can now be let go. Nichols (1997) stated that many agencies such as Denver PD and Los Angeles PD have complied with the law. However, the author fails to mention how many agencies have not complied with the law or sought court actions to fight the law. Only a Defense spokesman for the Air Force admitted not complying with the law and aired his opinion (abid.).

Recently in Oregon, legislation has been introduced by the North East Portland Precinct commander on 2/12/97 to the Oregon State Legislature called House Bills 2433 and 2432 (The Victory Group, 1997). These bills will address issues relating to traffic stop procedures by police and Officer Safety when making traffic stops. Both bills make reference to "...circumstances as necessary to ensure the officer's safety, including an inquiry regarding the presence of weapons or controlled substances" (HR2433). In my conversations with the NE commander, present statutes prevent officers asking drivers or their occupants about weapons due to privacy issues. However, according to the proposed legislation, the officer when confronted with a traffic violation or a traffic investigation, the officer can now claim that his safety is 
threatened. Therefore, the officer can "make any inquiry that is necessary to ensure the safety of the officer, including an inquiry regarding the person's possession of weapons or controlled substances" (HR2432).

The NE commander feels he has the support from most law enforcement officers in Oregon. He feels that it is not to much to ask a driver or occupants these questions for of the safety issues of the police and the police have reasonable suspicion that a law has been violated. The new legislation makes several references to reasonableness as does most legal documents. However, the question that must be asked is whether the inconvenience of citizens by police arrest in order for the jury to define reasonableness is not infringing upon privacy rights? The NE commander feels that he and the police community are not infringing upon the citizens privacy rights. However, does the rank and file law enforcement community share their higher administrative positions?

Past research on rank and file law enforcement officer attitudes on concealed carry and gun control is minimum. Of course, one can remember photo-op media images televised of police officers and their superiors on TV during the Brady Bill and Assault Weapon Ban debates. These images tended to show a progun control position. However, past research which is available has shown certain inconsistencies opposite of mainstream projections. One factor that has been consistently critical to the anti/pro-gun 
stance is whether officers own off duty firearms. Police officers have a standard handgun issued upon hire in most cases. Police officers according to the literature who own other than their duty firearms tend to be pro-gun for citizens. The opposite stance of anti-gun for those officers who do not own off duty firearms also is consistent. 


\section{HYPOTHESIS}

To address the problems of mass proliferation of handguns in the United States along with the lack of protection by police, the present researcher has developed a study to unlock the rank and file officer attitudes toward gun control. The present researcher hopes to answer the following hypotheses:

Hypothesis 1: If police don't have a legal duty to protect the law abiding citizen, wouldn't they favor citizens the right to carry concealed handguns?

Hypothesis 2: Older police officers will tend to be less likely to support gun control laws.

Hypothesis 3: Police officers who own personal firearms other than their duty weapon are less likely to support restrictions on ownership or prohibition.

Hypothesis 4: Police officers who have been exposed to deadly force in the line of duty are more likely to be more supportive of the control of guns then those who have not encountered deadly force.

Police should be supportive of citizens carrying concealed handguns for their own protection as stated in Article 1, Section 27 of the Oregon Constitution. As stated in the previous article Kleck et al. ,(1996) police and citizens alike can deter crime if the costs of crime are enhanced along with the benefits of crime reduced. 


\section{RESEARCH METHODOLOGY}

A total of 500 questionnaires were distributed to 6 municipal police agencies in the state of Oregon. The total amount returned accumulated to 247 questionnaires for a return rate of around 50\%. 1 returned questionnaire was disqualified from being used in the study for the officer filled it out at the time of the participation request. The final sample gathered for this study is comprised of 246 certified BPSST police officers from 6 municipal police agencies in the state of Oregon. Since Oregon is a diverse state with different rural and urban areas, several municipal police agencies-both rural and urban-were surveyed. Municipal police officers will be surveyed since they have most citizen encounters. Since the total list of certified BPSST officers from the state of Oregon was not available, a random sample was not utilized.

Therefore, the present researcher attempted a purposive sample trying to represent rural and urban police agencies in the state of Oregon. The researcher contacted the chief law enforcement officer at a potential participating agency (Lieutenant, Captain or Sergeant). Instructions as to the nature of the study fulfilling the requirements for my Masters degree were conveyed. He then decided to participate or not to participate in the study. The researcher gained participation from Medford Or. PD, Salem Or. PD, Astoria Or. PD, Bend Or. PD, Washington County Or. Sheriff's Office and two precincts of the Bureau of Portland Or. PD. Out of all 
the departments asked to participate, Cannon Beach Or. PD, Hillsboro Or. PD, and Seaside Or. PD did not return my calls and did not participate in the study. This purposive sample hopes to better reflect the small rural police agencies like Astoria Or. PD through medium police agencies like Salem Or. PD to a big metropolitan police agency like the Bureau of Portland Or. PD. Since the total list of certified officers from each agency was not available from the commanding officer, we agreed on a representative number proportionate to the total staff.

Out of the 246 rank and file officers who participated, $89 \%$ were male and $11 \%$ were female. The age of the participating officers ranged from 21 years old to 52 years of age. The mean age of those participating officers was 38.5 years old $(\mathrm{sd}=8.51)$. One respondent declined to list his/her age in the questionnaire. Total police experience was categorized into two brackets ranging from 0-14 years and 15 years or more. The mean years of police experience for the participating officers was $13.29(\mathrm{sd}=7.95)$. Two participating officers declined to give their total years of experience. The years of experience on average was larger than previous studies. Also, the average age of the officers was older than previous studies. This sample contained officers who tended to be of senior tenor.

The objective of this Master's Thesis is to review past literature against current Oregon rank and file police officers' attitudes toward the 1989 Oregon law and gun control in general. 
With these attitudes uncovered, proper policy for citizen-police encounters involving those legally carrying concealed handguns can be developed. To accomplish this task, a one page questionnaire has been formulated. Questions 1 through 3 addressed issues of: Police officers attitudes toward present Oregon gun laws and their effectiveness toward crime reduction and deterrence. Questions 4 though 6 addressed issues of requirements that prospective gun buyers must adhere to before acquiring a handgun. Question 7 addressed the attitudes of police officers toward individuals carrying concealed handguns. Questions 8 though 10 addressed severe legislative restrictions on citizen gun owners like prohibition, licensing and registration. Question 11 addressed police involvement in the training of citizens in firearm safety before they can take possession of a handgun. Questions 12 through 16 addressed issues of police officer gun ownership, issues of deadly force and recreation utilizing firearms. Finally, questions 17 through 19 asked demographics about the participants including sex, age and police experience of the participating officers. The present researcher excluded names to maintain anonymity.

A Likert scale ranging from strongly agree to no opinion is utilized for questions 1 through 11. Questions 12 through 16 involve a general yes or no answer. Items 17 and 18 ask the respondent to fill in the blank involving years of experience and age. Lastly, Item 19 asked the respondent to self-identify their 
gender by choosing male or female. The questionnaire was printed on 8.5 by 11 inch white paper and was enclosed within a \#10 white envelope with the researchers address and paid postage to ensure anonymity and little inconvenience. There was no request for the officers name or return address on the envelope. There was no further contact with the subjects after the questionnaires was administered. Since the questionnaire will only take 10-15 minutes to complete, the officer will not be inconvenienced. Lastly, after all data are compiled from the completed questionnaires, they will be destroyed after one year to ensure final anonymity. 


\section{LIMITATIONS OF STUDY}

When the present researcher reviewed the methodology several issues and problems emerged. The first problem is external representation of attitudes. Since the total BPSST list of Oregon police officers did not exist, the forementioned results cannot be representative of total Oregon police officers. In addition, police officers in Oregon reflect varying values and culture. Therefore, these results cannot be representative of all officers as a whole within the US. The second potential problem with questionnaires is internal validity. Can the present researcher be certain that the respondents attitudes will reflect their behavior? The questionnaire instrument may have persuaded the respondent to want to be perceived in a good way; therefore, persuading the officer to respond in a specific way. Once could say the same for the respondents in the past literature including Norman et al. (1983) and Siwik et al. (1984) ect... Next, the problem of politics may have influenced the responses of the officers. Since the chief law enforcement officer for each department was approached for permission, he may have given directions for respondents. Therefore, mainstream attitudes within the law enforcement community may have had influence on the decision making process. 


\section{RESULTS AND DISCUSSION}

Hypothesis 1 which stated that due to legal precedent of Police Officers not being liable to protect the individual from the criminal element, they should be supportive of citizens carrying concealed handguns for their own protection as stated in Article 1, Section 27 of the Oregon Constitution. This hypothesis was shown to be accurate to a degree. However, the researcher can only make a correlation between precedent and attitude. Results from question 1 (Current Oregon gun laws prevent gun violence) found that out of the 246 respondents, $51.6 \%$ strongly disagreed that Oregon gun laws prevent crime. $88 \%$ of the total participants disagreed that Oregon gun laws prevent crime. Results from question 2 (Current Oregon gun laws prevent criminals from obtaining handguns) found that out of 246 participating officers, $63.4 \%$ strongly disagreed with the premise that criminals get their guns legally. A total $90 \%$ of the participating officers feel that Oregon gun laws do not prevent criminals from obtaining guns. These results are consistent with Siwik et al. (1984), Norman et al. (1983), and Doran (1994) that criminals get their guns illegally. Results from question 3 (Current Oregon gun laws prevent the shooting of police officers) found as in Q1 \& Q2 that a majority of the respondents strongly disagreed by $61.4 \%$ and disagreed by $32.1 \%$ with the premise. A total of $94 \%$ disagreed that Oregon gun laws with there sanctions prevent the use of deadly force against officers. 
These results are consistent with the past literature Siwik et al (1984), Norman et al. (1983). In Norman et al (1983), 93\% of the officers felt that present gun laws do not prevent gun violence and $94 \%$ of the officers felt present laws do not prevent criminals from obtaining guns. Finally, $90 \%$ felt that present gun laws do not deter the killing of police officers. Siwik et al. (1984) did not address the same issues verbatim but addressed possible future gun control legislation involving gun violence and the sanctions that would deter handgun violence. The results from Siwik (1984) found that $60 \%$ of the participating officers felt that stronger handgun laws would not reduce handgun crime. $89 \%$ of the participating officers felt that future laws would not prevent criminals from obtaining handguns. The issue of deterring the killing of police officers was not addressed. However, by and large the rank and file police officer does not feel that laws prosecuting firearm perpetrators and their sanctions will deter future crime.

When addressing issues of requirements for a prospective gun buyer to follow before acquiring a handgun, the results were quite the opposite from the aforementioned and in past literature. Results from question 4 (I favor criminal background investigations before a person can buy a handgun) found $84.6 \%$ of the participating officers strongly agreed with the premise along with $13.8 \%$ who agreed. A total of $98.4 \%$ of the participants agreed that criminal background investigations should take place. This data shows consistencies with Siwik et al.(1984) and Norman et al. 
(1983). Results from question 5 (I favor a waiting period before a person can buy a handgun) found $64.6 \%$ of the participating officers strongly agreed with waiting periods along with the $21.5 \%$ who agreed with the Brady Bill. A total of $86 \%$ of the participating officers feel that a waiting period should occur before a prospective handgun buyer takes possession of a handgun. Once again, the present data shows consistencies with the literature review like Lester (1983), Siwik et al.(1984) and Norman et al. (1983).

Results from question 6 (I favor mandatory safety courses before a person can buy a handgun) found that $51.6 \%$ of the respondents strongly agreed with training along with $30.1 \%$ who agreed respectively about safety courses. A total of $82 \%$ feel that citizens wanting to own a handgun should take a safety course. This result is consistent with Lester (1983), where officers supported safety training. As in the previous literature Siwik et al. (1984) and Norman et al. (1983) regarding items 4-6, rank and file officers support these types of precautionary measures before a person can own a handgun. One could speculate that since officers need to undergo these types of personal qualifications before they can carry a handgun, the public at large should be held to a similar standard.

When the researcher reviewed the results from Question 7 (I favor allowing qualified persons carry a concealed handgun). One found that $28.5 \%$ of the respondents strongly agreed along 
with $45.5 \%$ who agreed that citizens should be allowed to carry concealed handguns. A total of $75 \%$ of the participating officers agree with citizens carrying handguns for self protection. This result supports hypothesis 1 despite what higher administrators feel about concealed carry permits. However, one can only speculate that legal precedent is the reason why police support this issue. On the other hand, Lester (1983, p.7) showed contrasting results from the present study with those officers supporting prohibition of citizens carrying handguns in their cars. In Oregon, having a handgun in ones car out of plain sight is considered carrying concealed. Therefore, Oregon police officers in the present study support concealed carry laws compared to $\mathrm{NJ}$ officers in Lester (1983). Also, these results support some of the issues raised in the articles to be found in the publication $\underline{\mathrm{Law}}$ Enforcement of America. While many officers seem to play the politically correct game, thousands of rank and file officers including the present study support ones right to keep and bear arms.

Questions 8-10 addressed issues of severe restrictions on the right to keep and bear arms. Will the results be supportive as with waiting periods, background checks, and safety courses? Or, will the results be opposition as allowing the freedom to carry and own firearms? Results from question 8 (I favor licensing those persons who want to buy a handgun) found $25.6 \%$ of the responding officers strongly agreed with the premise along with the $35 \%$ who 
agreed. While supportive, the total $62 \%$ is not as decisive and absolute as with previously mentioned restrictions. Norman et al. (1983) and Siwik et al. (1984) did not address this issue. However, the present study shows support by the rank and file to license handgun owners. Results from question 9 (I favor the registration of all handguns) found $36.6 \%$ of the respondents strongly agreed with the premise of registration along with the $26.8 \%$ who agreed. A total of $63 \%$ of the participating officers favor registration. Once again there is not as a decisive opinion on this issue as on waiting periods, safety training and investigations. These results are similar to Siwik et al. (1984).

However, what is interesting is that after all the support for waiting periods, licensing, registration, safety courses, ect... the results for prohibition are equal to Siwik et al. (1984), Norman et al. (1983) and Lester (1983). The results from question 10 (I favor making the ownership of a handgun illegal except for police or the military) found an overwhelming $58.9 \%$ of the respondents strongly disagreeing along with $30.5 \%$ who disagreed with prohibition. A total of $90 \%$ of the participating officers felt that prohibition was not necessary for crime control. Both the past literature and the present study show that rank and file by and large support waiting periods, safety courses, criminal background checks, licensing, registration, ect... However, the degree of support diminishes as the severity of the restriction escalates. 
On the other hand, police officers favor citizens carrying concealed handguns. One could draw the conclusion that the law enforcement community wishes to hold the average citizen to similar standards as a police officer when it comes to handgun ownership. One thing is consistent in the past and present, police officers do not want handgun or firearm prohibition. In fact, the police want more involvement in the training of police officers. In regards to the results from question 11 (I favor police involvement in training those people who want concealed carry permits) found that $21.5 \%$ of the respondents strongly agreed along with the $41.1 \%$ who agreed that police be involved with citizens wanting to learn how to handle and own firearms safely. A total of $63 \%$ of the participating officers want to help citizens become safe firearm owners.

Question 12 asked (Do you own a firearm other than your duty weapon) in which the results showed $89.8 \%$ of the participating officers owned a firearm other than their duty weapon. This result is not surprising considering the large hunting population in the state of Oregon. Only $10.2 \%$ of the respondents declared that they did not own an additional firearm. Results from question 13 (Do you hunt or shoot recreationally?) found that $63 \%$ of the respondents answered in the affirmative while $37 \%$ responded no. Results from question 14 (Do you shoot on a regular basis other than qualifying with your duty weapon?) found a even split with $50.4 \%$ answering affirmatively and $49.6 \%$ responding 
negatively. Results from question 15 (Have you ever fired your weapon in the line of duty?) found that most officers have not had to fire their service weapon in the line of duty. Only $27.6 \%$ of the responding officers answered that they had fired their firearms in the line of duty. Lastly, results from question 16 (Have you ever been shot or shot at?) found $41.1 \%$ of the respondents have been shot at or returned fire while $58.5 \%$ of the respondents have not been shot at or returned fire.

As the present researcher looked at the demographics of the sample population, additional hypothesis emerged. The mean age of the respondents and years of experience was similar to Norman et al. (1983). However, the mean age and years of experience was greater than Siwik et al. (1984). If rank and file law enforcement officers as a whole supported gun control, would there be distinguishing attitudes among the old and the young? One would think that older Oregon police officers hunt more often, were socialized at an early age to utilize firearms and therefore, be less supportive of gun control. Therefore, could one address the issue of attitudes toward Oregon gun control laws based on distinguishing the old and the young, the experienced and the inexperienced? The present researcher intends to address that one issue.

Results from question 4 addressing differences between younger and older officers and their opinions toward performing criminal background investigations on new handgun buyers seem 
to disprove my hypothesis 2. Among the older \& younger officers, there is no difference in attitudes toward background investigations. In this case, younger officers (87\%) strongly agreed with the premise. Older officers showed similar results where $83 \%$ of the participating officers strongly agreed that background investigations should take place. When one adds the agree data to the young and old respondents, an overwhelming $100 \%$ of the younger officers and $97 \%$ of the older officers support background investigations.

Results from question 5 addressing differences between younger and older officers and their opinions towards waiting periods before a handgun buyer takes possession of the handgun shows similar attitudes but not as absolute. $63 \%$ of the younger officer respondents strongly agree that waiting periods should occur before a buyer takes possession of a handgun. Older officers show similar attitudes with $68 \%$ of the officers strongly agreeing that waiting periods should occur. When one adds the agree data, $86 \%$ of the younger officers and $89 \%$ of the older officers feel that waiting periods should take place. 


\section{DIFFERENCES BETWEEN YOUNGER AND OLDER OFFICERS ON SAFETY TRAINING.}

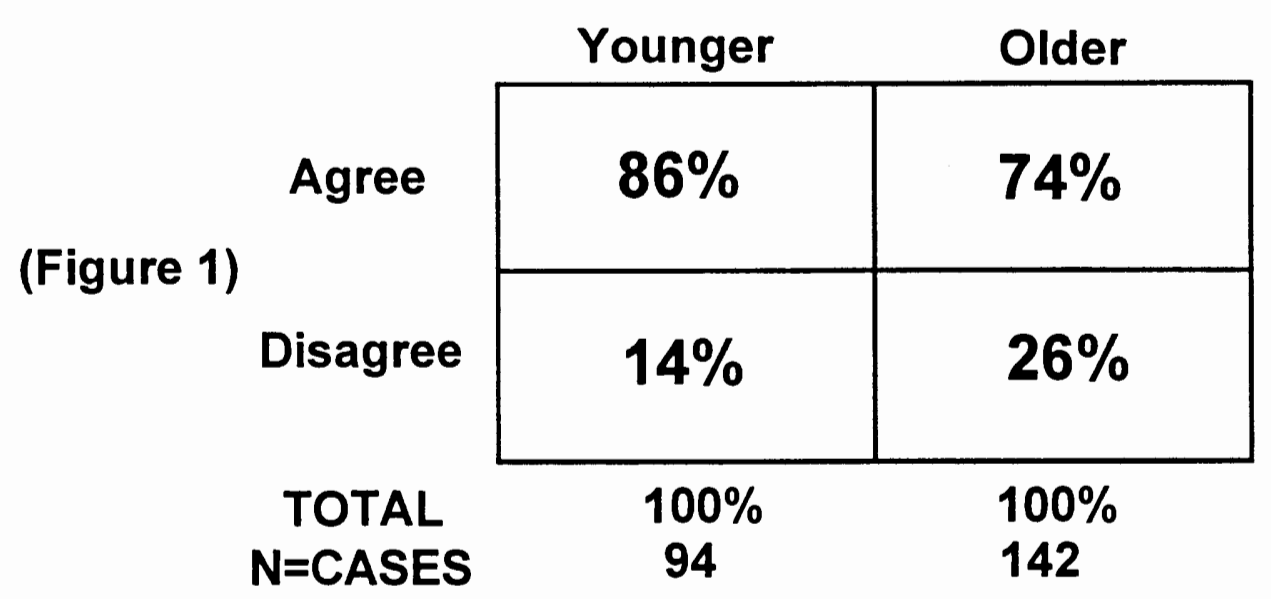

Results from question 6 (Figure 1) addressing differences between younger and older officers and their opinions toward safety training for prospective buyers show consistent trends to past literature but with a slight diffeence. $54 \%$ of the younger officers strongly agree that new buyers of handguns should take a safety course. Older officers have similar attitudes with 53\% strongly agreeing. When one adds the agree data, a total of $86 \%$ of the younger and $74 \%$ of the older officers support mandatory safety training for prospective buyers. While there is consistent support, older officers are more likely to disfavor safety training. However, is there any distinction amongst older and younger officers when it comes to supporting concealed carry permits. 


\section{DIFFERENCES BETWEEN YOUNGER AND OLDER OFFICERS ON CONCEALED CARRY PERMITS.}

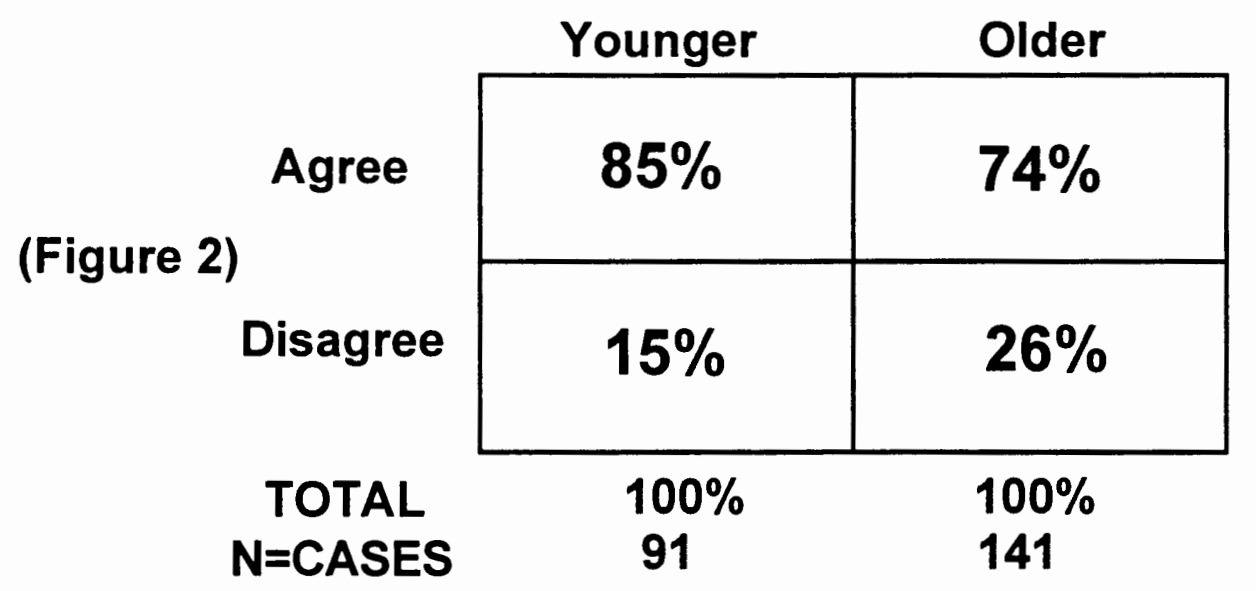

Results from question 7 (Figure 2) addressing differences between younger and older officers and their opinions toward the issuing of concealed carry permits while not showing significant differences amongst older and younger officers do show positive support. Younger officers who strongly agree with concealed permits for citizens amounted to $33 \%$ as did older officers with $28 \%$ strongly agreeing. However, when one takes into consideration the agree data, the results are more in favor by and large. Younger officers show a total of $85 \%$ in favor of concealed permits. Older officers show similar results totaling $74 \%$. While there is not a significant difference, younger officers are more likely to support concealed carry permits than their older counterparts. 


\section{DIFFENCES BETWEEN YOUNGER AND OLDER OFFICERS REGARDING LICENSING HANDGUNS.}

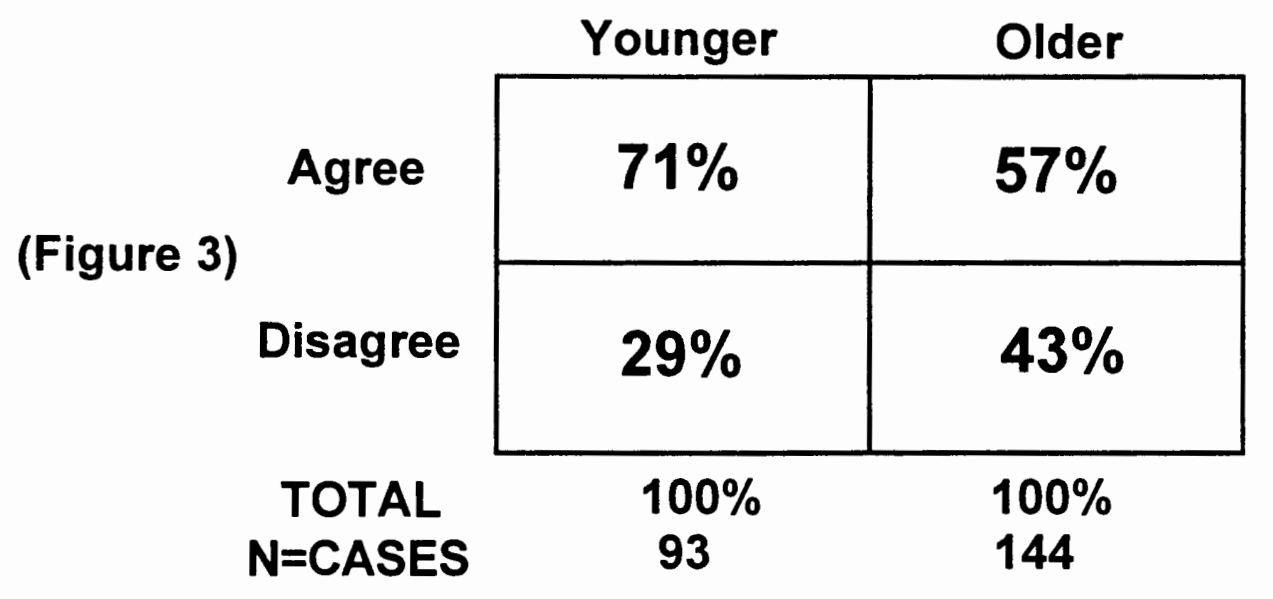

Results from question 8 (Figure 3) addressing differences between younger and older officers and their opinions toward licensing handgun owners does show a small significant difference between younger and older officers. Younger officers strongly agree in $27 \%$ of the cases that handgun owners should be licensed. When one adds the agree data, the support for younger officers jumps to a total $71 \%$. Among older officers, $26 \%$ of the cases show strong support for licensing handgun owners. When one adds the agree data, only $57 \%$ of the total cases support licensing handgun owners. Therefore, younger officers are more likely to support licensing handgun owners compared to their older counterparts. 


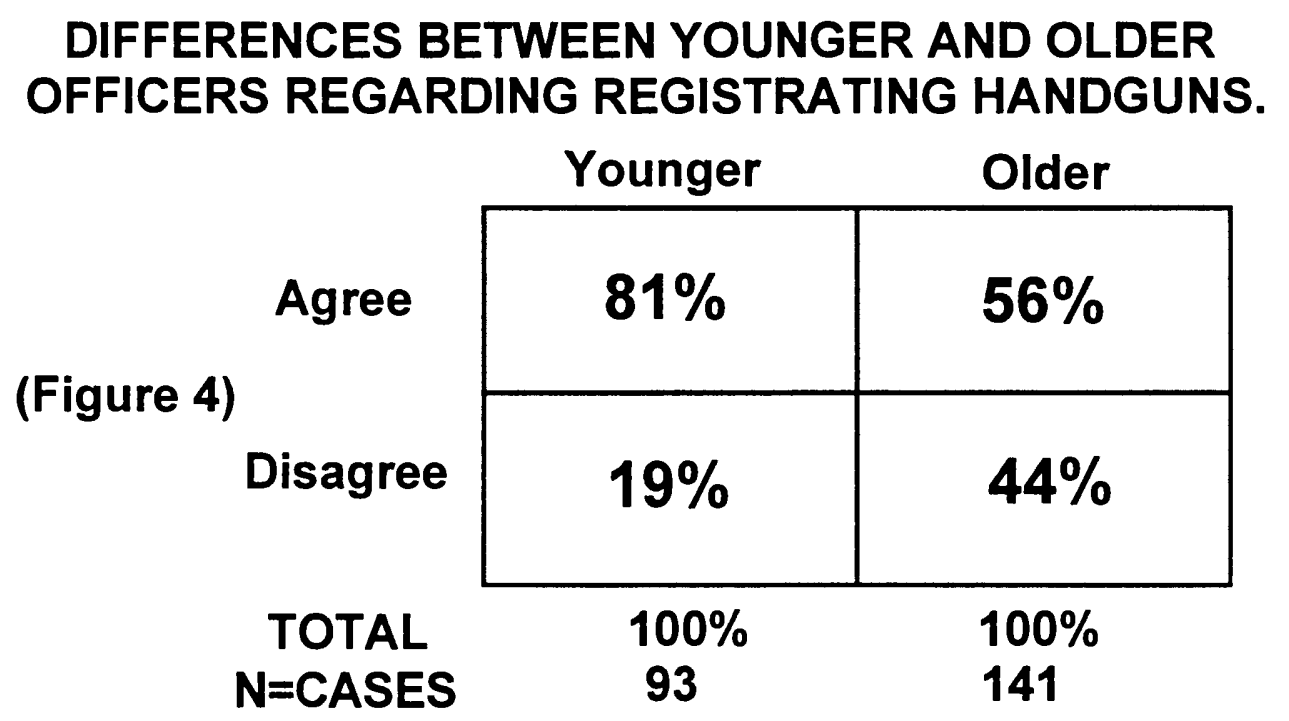

Results from question 9 (Figure 4) addressing differences between younger and older officers and their opinions toward registration of handgun owners also show significant differing results. Of the responding young officers, $49 \%$ of the cases strongly support registration. When one adds the agree data, a total of $81 \%$ of the younger officers support registration of handgun and firearm owners. However, the attitudes for older officers differ with $32 \%$ of the cases strongly supporting registration. The total response rate for older officers who support registration is only $56 \%$. In this case, there is a $25 \%$ less likely chance that older officers will support registration compared to their younger counterparts.

Results from question 10 addressing differences between younger and older officers and their opinions toward prohibition of handgun ownership except for police and the military show 
almost the exact same results. Younger officers in this case strongly disagree with $62 \%$ of the cases that prohibition should not take place. When one adds the disagree data, a total of $91 \%$ of the younger respondents disfavor prohibition. Older officers show a similar attitudes with $59 \%$ of the cases strongly disfavoring prohibition. Older respondents disfavoring the prohibition premise total $92 \%$ of the cases.

It is apparent that there is no major significant differences among older and younger officers when it comes to purchasing precautions such as background investigations and waiting periods. Both groups support either premise. These results are consistent with the past literature. There is some slight differences between older and younger offices when it comes to safety training and concealed carry permits. However, there is significant differences between older and younger officers when addressing registration and licensing handguns. Lastly, as in the past and present literature both, older and younger officers disfavor prohibition. 
DIFFENCES BETWEEN YOUNGER AND OLDER OFFICERS REGARDING POLICE INVOLVMENT.

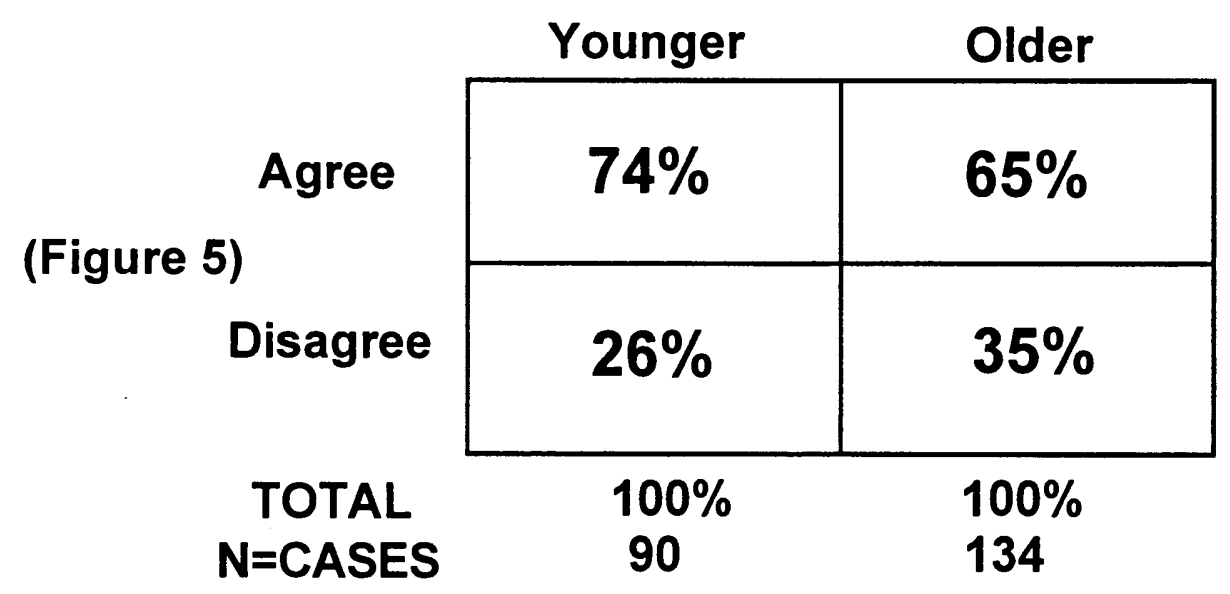

Lastly, when addressing differences between younger and older officers and their opinions toward police involvement there is little differences but support. Police training is defined as officers instructing and participating alongside citizens as they become safe, proficient handgun owners. Results from q11 (Figure 5) show that younger officers strongly support police involvement in $23 \%$ of the participating cases. The older officers show little difference with $24 \%$ of the participating cases strongly supporting police involvement. However, total support for police involvement is $74 \%$ for the younger officers and $65 \%$ for the older officers.

The present researcher felt that the officers in question might sympathize with the second amendment movement in this country. Therefore, police officers (especially older) who shoot recreationally might not agree with the restrictions and 
prohibition attitudes of the larger uninformed society. In reviewing the results, age had little if nothing to do with lowered support of precautionary restrictions. In regards to hypothesis 2, when addressing waiting periods, background checks, ect... the hypothesis is disproved. However, when addressing severe restrictions like licensing and registration, the hypothesis is proven.

Hypothesis 3 addressing personal gun ownership with the support for criminal background investigations from $\mathrm{q} 4$ found that nothing has changed. Out of the 221 officers who owned personal firearms, $84 \%$ strongly agreed with the premise of criminal background investigations compared to $88 \%$ of non-owners. When the agree data is included, $99 \%$ of owners agreed that criminal background investigations take place compared to $97 \%$ of nonowners. Personal ownership of off duty firearms by officers had no significant effect on attitudes toward background investigations.

Next, out of the 216 officers who owned personal firearms, $64 \%$ strongly agreed that waiting periods (q5) should occur compared to $84 \%$ of non-owners. When the agree data was taken into account, $87 \%$ of the owners agreed that waiting periods should occur compared to $92 \%$ of non-owners. While there is a slight difference between owners and non-owners relating to waiting periods, by and large the rank and file support waiting periods. These results are consistent with Siwik et al. (1984) where $89 \%$ of 
both owners and non-owners agreed with the premise of waiting periods.

Thirdly, out of the 212 police officers who own personal firearms other than their duty weapon, $51 \%$ strongly support safety training (q6) compared to $76 \%$ of non-owners. Agree data added to the strongly agree results total $84 \%$ of the owners supporting safety training compared to $92 \%$ of the non-owners. While non-owners of firearms show more support for safety training for prospective handgun buyers, both groups support the premise. How does personal ownership of off duty firearms effect attitudes toward concealed carry permits.

The results from the 209 police officers who owned personal firearms showed positive attitudes toward concealed carry permits. $31 \%$ of the owner cases strongly agreed that citizens should have concealed handgun permits compared to $25 \%$ for nonowners. However, when the agree data is included, the support for citizen concealed permits increases to a total of $79 \%$ amongst owners compared to $71 \%$ of non-owners. In this case, officers who own off duty firearms and participate in the shooting sports tend to show a little more support for concealed carry permits. One might speculate that they support ones right to keep and bear arms compared to non-owners. 


\section{DIFFERENCES BETWEEN FIREARM OWNERS AND NON-OWNERS ON LICENSING HANDGUNS.}

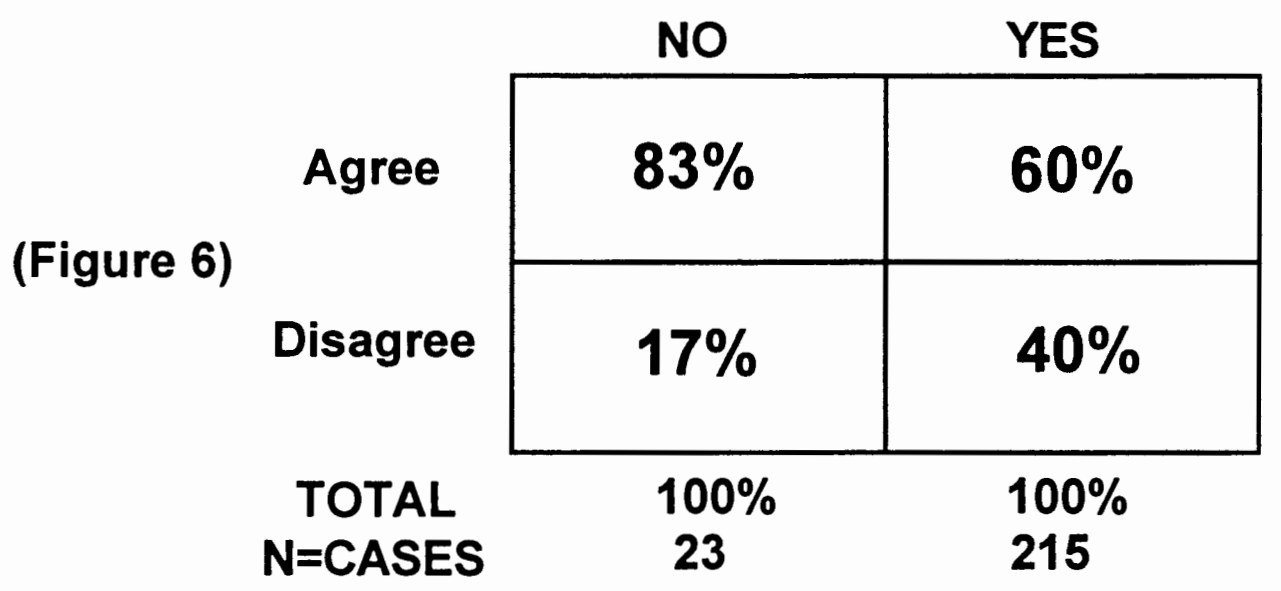

Out of the 215 officers who own firearms, $25 \%$ of the cases strongly support licensing handgun owners (Figure 6) compared to $44 \%$ for non-owners. The total support for licensing handgun owners amongst owners consists of $60 \%$ and $83 \%$ for non-owners. While owners do support licensing by a greater than $50 \%$ margin, it is not as overwhelming as for non-owners who do support licensing. These results are not as significant as Siwik et al (1984) which showed that those officers who owned firearms other than their duty weapon, and showed more proficiency were less likely to favor licensing citizens (55.8 D/SD) compared to non-owners (17.2 D/SD). Nonetheless, non-owners are more likely to support licensing $23 \%$ of the time than their owner counterparts. 


\section{DIFFERENCES BETWEEN FIREARM OWNERS AND NON-OWNERS ON REGISTRATION.}

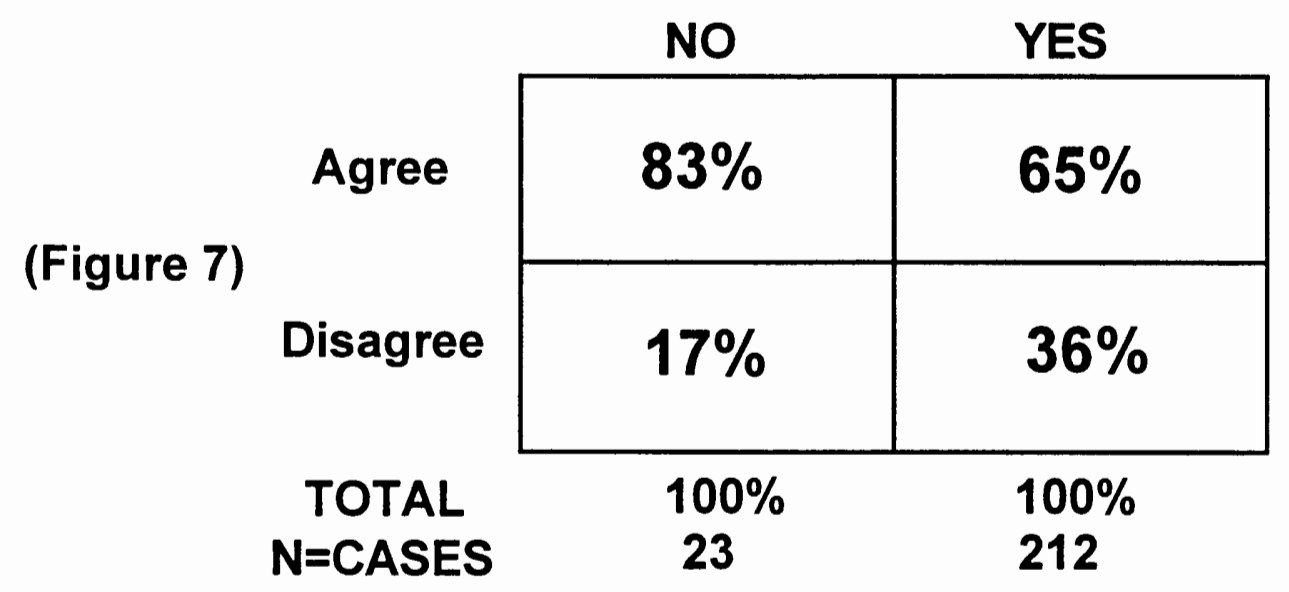

When police officers who own personal firearms are compared to non-officers and their attitudes on registration (Figure 7), differences continue to emerge between owners and non-owners. $37 \%$ of the owners strongly support handgun registration compared to $52 \%$ of the non-owners. Total support amongst owners for registration is $65 \%$ compared to $83 \%$ for nonowners. While there is a slight difference between owners and non-owners, these results are not as significant as Siwik et al. (1984). In his study, $53.8 \% \mathrm{D} / \mathrm{SD}$ with the premise of handgun registration compared to $17 \%$ of non-owners who D/SD. In the present case both owners and non-owners by majority support registration. However, owners are more likely to disfavor registration. 


\section{DIFFERENCES BETWEEN FIREARM OWNERS AND NON-ONWERS ON PROHIBITION.}

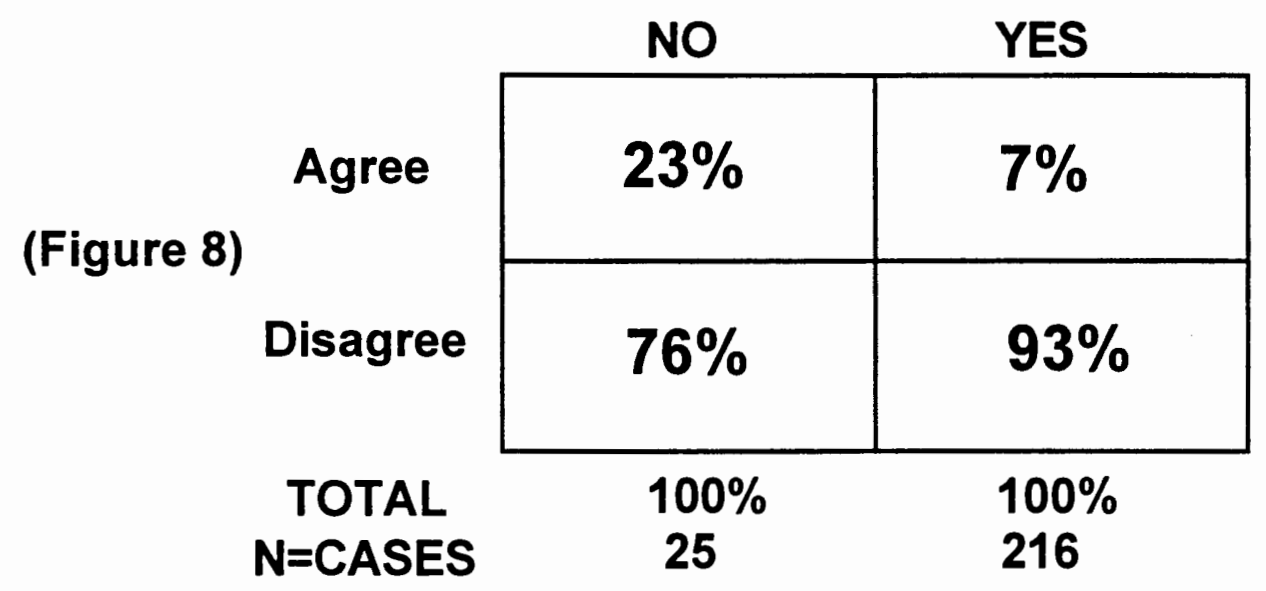

Lastly, when addressing the support for prohibition (Figure 8) amongst officers who own personal firearms, owners show more disfavor than their non-owner counterparts. Out of the 216 officers who own personal firearms, $63 \%$ strongly disfavor the prohibition of handguns amongst the citizenry compared to $32 \%$ for non-owners. When one includes the disagreed data, a total of $93 \%$ of owners and $76 \%$ of non-owners disfavor prohibition. These results tend to be consistent with Siwik et al. (1984) where owners were more supportive of a right to keep and bear arms than the non-owners. Therefore, in regards to hypothesis 3 the support for the hypothesis differs depending upon the severity of the restriction. Items 4-6 disprove the theory while 8-10 support the hypothesis.

Lastly, is there any difference between owners and nonowners when addressing police involvement in the training of safe 
firearm owners is measured. Out of the 201 officers who own personal firearms, $22 \%$ strongly support police involvement compared to $33 \%$ for non-owners. When one considers the agree data, a total of $69 \%$ of the owners and a total $67 \%$ of non-owners support police involvement in the training of citizen handgun owners.

As with differing age groups amongst police officers, there seems to be no significant shift in opinion amongst officers who own personal firearms and their support for certain gun control proposals. By and large their is strong support for background investigations, waiting periods, safety training and one could even say concealed permits. As one proposes more severe restrictions like registration and licensing however, the support begins to dwindle. In fact, there even emerged distinctions amongst owners and non-owners. Lastly, prohibition is consistently refuted as a viable option amongst differing ages and those who own personal firearms. By and large the present researchers third hypothesis is disproved.

Can one make the same claim amongst gender. How do females differ from their male counterparts when it comes to gun control? While it is apparent that the majority of participants were male, there can be some conclusions made about the female participants. However, the present researcher does not claim that the female proportion of the sample is representative of the population. 
Results from q4 addressing differences between males and females toward background investigations show insignificant differences. As with the male counterpart (84\%), female officers strongly agree in $93 \%$ of the cases that background investigations should take place. Agree data brings the female total to $96 \%$ in support for background investigations and $99 \%$ for men.

When addressing males compared to females and their attitudes toward waiting periods there tends to be similar results to their male counterparts. Out of the total female participating sample, $82 \%$ strongly agreed that waiting periods should occur compared to $64 \%$ for men. A female total of $96 \%$ support waiting periods and a total of $87 \%$ of the men support waiting periods. While there is support overall and no major differences between men and women, women tend to be more likely to support waiting periods compared to men.

Thirdly, when comparing male and female attitudes toward mandatory safety training for prospective handgun buyers, $70 \%$ of the females strongly support the training compared to $51 \%$ of the men. A total of $89 \%$ of females support training while a total of $84 \%$ of the men support training. Once again while there is no major differences amongst men and women, the women tend to be more absolute and decisive 
DIFFERENCES BETWEEN MALES AND FEMALES TOWARD CONCEALED CARRY PERMITS.

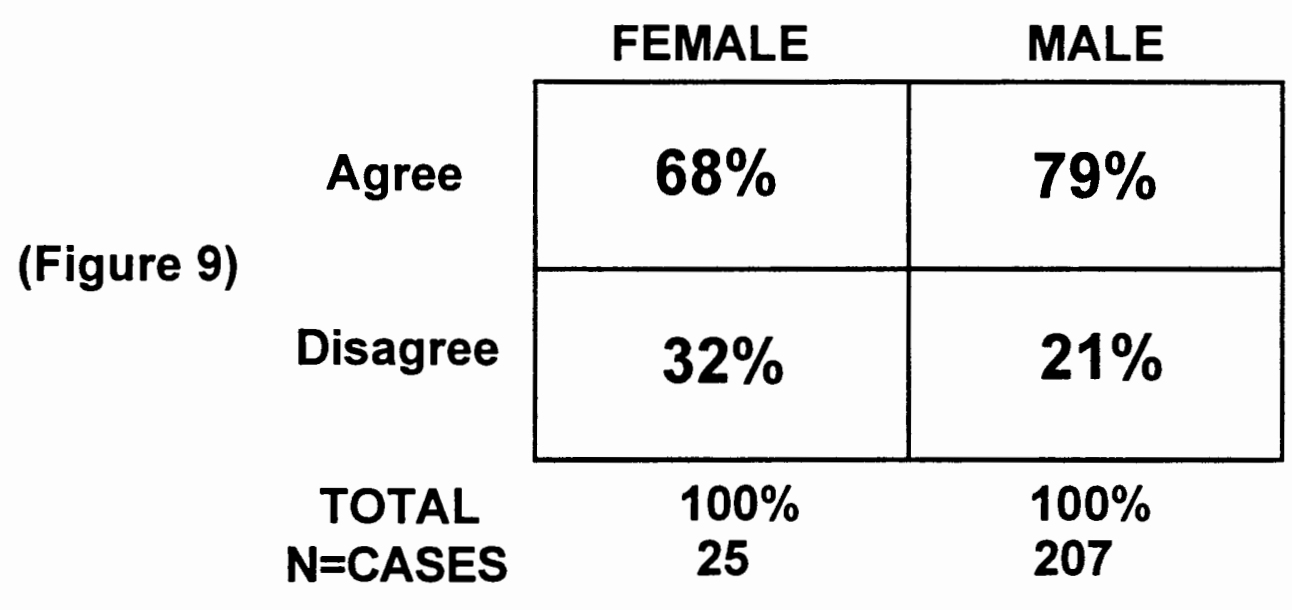

Are the females consistent with their male counterparts when they address the issue of concealed handgun permits (Figure 9)? Out of the female participants, only $12 \%$ strongly support citizens who want to carry handguns compared to $31 \%$ for men. When the agree data is included, a total of $68 \%$ of females support citizens carrying concealed handguns compared to $79 \%$ of the men. According to the literature, men tend to be more absolute and decisive on this issue for men tend to own more firearms than women overall. Men tend to shoot more often, have a more personal relationship surrounding other males and firearms and therefore, be more supportive of a persons right to keep and bear arms. 


\section{DIFFERENCES BETWEEN MALES AND FEMALES REGARDING THE LICENSING OF HANDGUNS.}

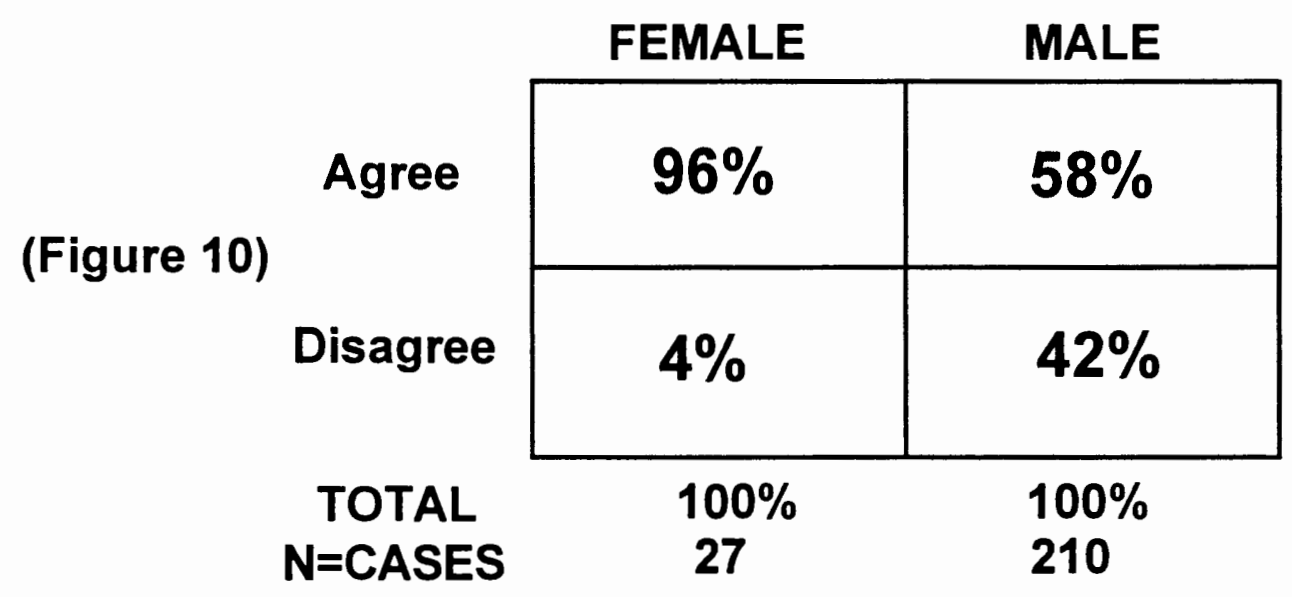

Next, when comparing male and female attitudes toward licensing handgun owners (Figure 10), $41 \%$ of the females strongly support licensing handgun owners compared to only $25 \%$ of men. The total support for licensing handgun owners amongst women is 96\%. This result becomes significant when compared to their male counterparts whom their total support for licensing adds up to $56 \%$. Therefore, one could speculate that men own more firearms, shoot more often and tend to be less favorable toward severe restrictions than their female counterparts. Women on the other hand are more likely to be victims of firearm violence. Therefore, female officers tend to sympathize with their victim counterparts and therefore support tighter restrictions. 


\section{DIFFERENCES BETWEEN MALES AND FEMALES REGARDING THE REGISTRATION OF HANDGUNS.}

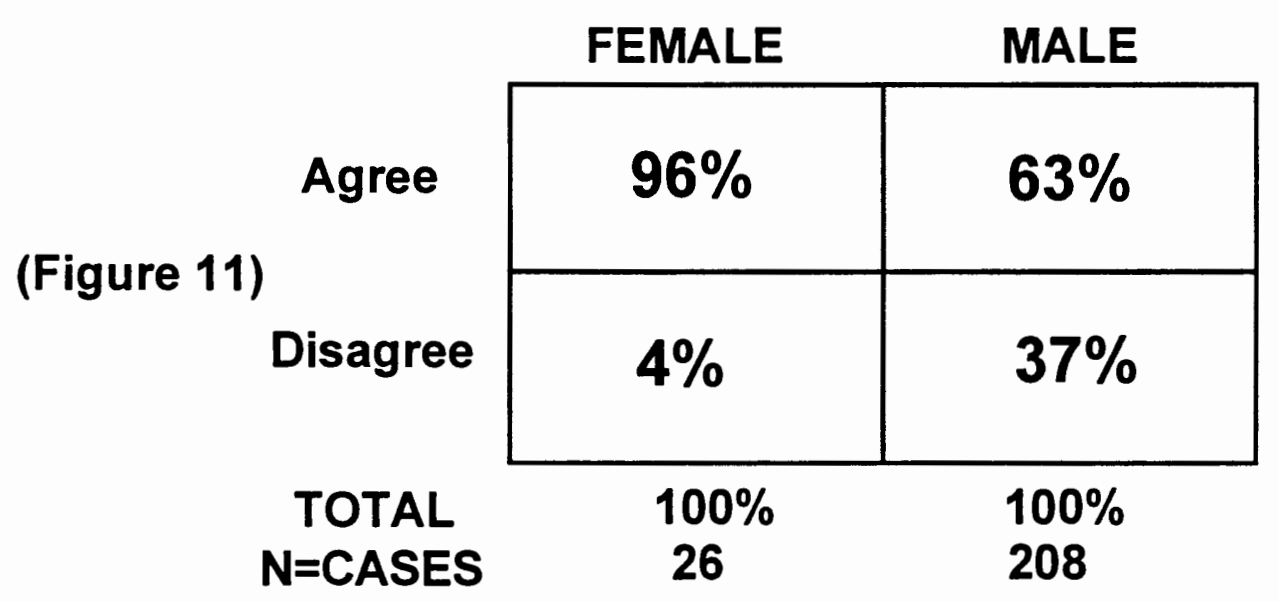

Is their support for licensing as strong as it is for registration (Figure 11). Out of the female participants, 69\% strongly support registration of handgun owners. Males on the other hand total $35 \%$ of the participants strongly supporting the premise. A total of $96 \%$ of the females support this restriction. Males however only show a total of $63 \%$ of the cases supporting registration. Once again their is a difference amongst men and women when it comes to registering handgun owners. Could one support the premise that increased victimization of women criminally and socially within society has led them to this support? In addition, females being more passive and less aggresive find the shooting sports and firearms in general less appealing. More study of this subject needs to be done.

Finally, does the support for prohibition amongst females match those on licensing and registration? Out of the female participants, $46 \%$ strongly disfavor prohibition. Males on the other 
hand strongly disfavor prohibition with $62 \%$ of the cases. When the disagree data is included, a total $86 \%$ of the females disagree with the premise of prohibition of handguns amongst the citizenry. Males on the other hand show more disfavor with prohibition with a total of $92 \%$ disagreeing. While it is apparent that female participants reflect their male counterparts on issues of waiting periods, background investigations, safety training and even concealed carry permits, and prohibition, the similarities end there. When addressing issues of licensing and registration, females are more likely to support these issues when compared to their male counterparts. Prohibition on the other hand is mutually unacceptable among women and men.

SHOULD THE POLICE BE INVOLVED IN THE TRAINING OF CITIZENS WHO WANT TO CARRY HANDGUNS?

FEMALE

MALE

(Figure 12)

\section{Disagree}

TOTAL

$N=$ CASES

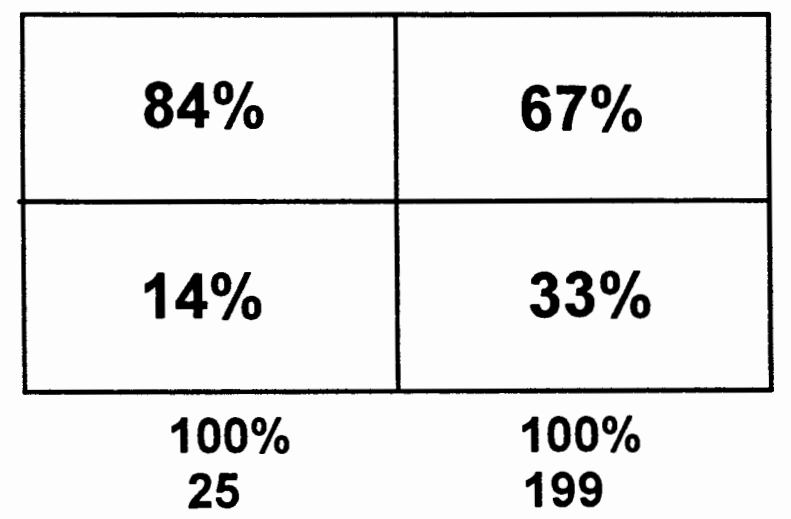

One issue that hardly comes up in the literature is how police officers feel about involving themselves in the training of citizens who want to own handguns. The present researcher in Figure 12 
addressed this issue. Amongst the females, $32 \%$ strongly favored police involvement in the training of citizens. Males on the other hand only strongly favored the premise by $23 \%$. The total support however does show some significant differences. Females by $84 \%$ support police involvement. Males on the other hand support the premise of police involvement $67 \%$ of the time. Can one say that male officers tend to disfavor training citizens for fear of encouraging firearm ownership? On the other hand, can one say that females support training to reduce victimization amongst females? More research needs to be done on the differences between males and females in the issue of firearms.

The last issue to be addressed is how officers who have encountered deadly force feel toward the control of guns. Previous studies including Norman et al. (1983) and Siwik et al. (1984) fail to address this most important issue. Hypothesis 4 will answer how officers who have encountered deadly force feel about gun control and those citizens who want to carry handguns.

In regards to favoring criminal background investigations for prospective handgun buyers, there is no significant difference between officers who have encountered deadly force and those who have not. $85 \%$ of the officers who have not encountered deadly force strongly agree with background investigations. Those officers who have encountered deadly force show a insignificant difference in support with $84 \%$ of the officers showing strong support. When the agree data is included, officers who have 
encountered deadly force total $98 \%$ in support compared to $99 \%$ of the officers who have not encountered deadly force.

When the present study addresses waiting periods for prospective handgun buyers, similar results from $\mathrm{q} 4$ emerge. Out of the total officers who have encountered deadly force, $64 \%$ strongly agree with waiting periods. Officers who have not encountered deadly force show similar trends with $68 \%$ showing strong support. When the totals are added up, $84 \%$ of those officers who've encountered deadly force support waiting periods compared to $91 \%$ for those officers who've not enountered deadly force. In this case there is a slight difference between officers who've been exposed to deadly force and those who've not. What is interesting is that those officers who've been exposed to deadly force are less likely to support waiting periods.

In regards to officers who've been exposed to deadly force and the issue of mandatory safety training, past trends of the present research continue. Out of the 96 officers who've been exposed to deadly force, $48 \%$ strongly agree with safety training before a handgun buyer can take possession of the handgun. The non-deadly force officers show greater support with $58 \%$ of the cases strongly supporting safety training. When the agree data is included, $82 \%$ of those officers exposed to deadly force support safety training but not as overwhelming as the non-deadly force officers. Out of the total 140 officers who've not been exposed to deadly force, $86 \%$ support mandatory safety training. As with the 
past 3 issues, officers who've been exposed to deadly force show slight insignificant less support for gun control.

\section{OFFICERS WHO'VE FACED DEADLY FORCE AND THEIR OPINION ON CONCEALED CARRY PERMITS.}

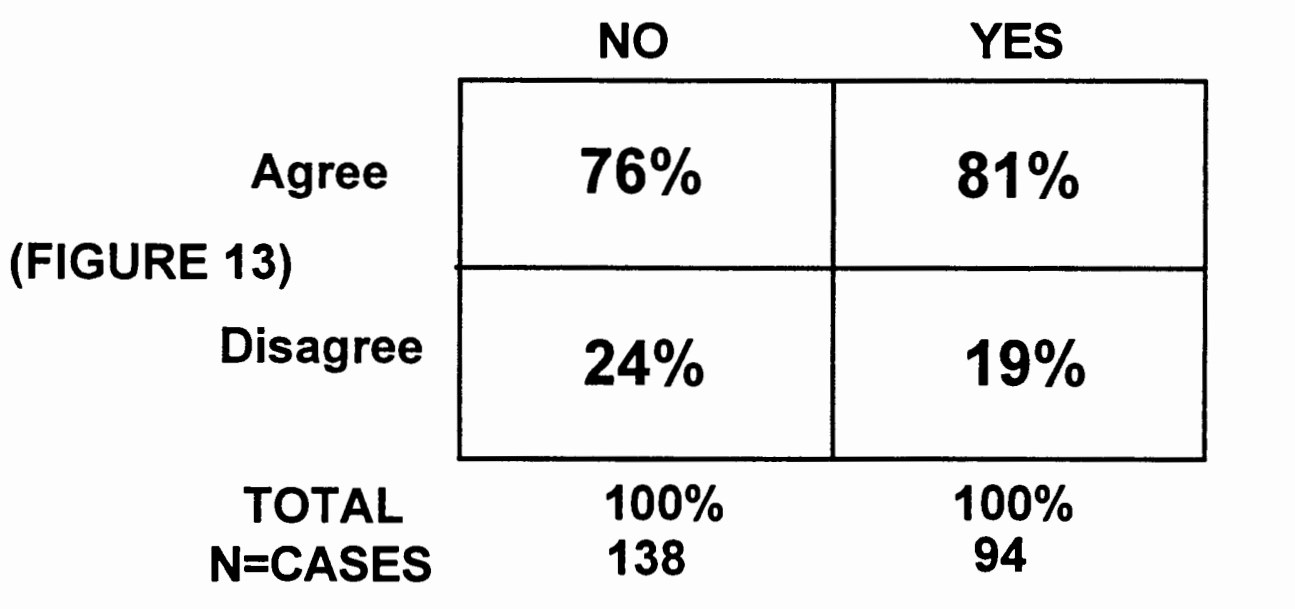

Out of all the issues relating to the control of handguns, the issuing of concealed handgun permits to citizens (Figure 13) should be the most important safety issue to those officers who have been shot at in the line of duty? One would think that keeping guns out of the hands of citizens would be these officers main concern? While results are not as clear cut as previous issues, there is still support for concealed carry permits. Out of the 94 officers who've been exposed to deadly force, $33 \%$ strongly support issuing concealed permits compared to the $28 \%$ of officers who've not been exposed to deadly force. When the total agree data is included, $81 \%$ of officers exposed to deadly force favor issuing concealed permits. Those officers who have not been exposed to deadly force show similiar results totalling $76 \%$ of the cases in support. 
While there is some disagreement about issuing these permits, those officers who have been shot at in the line of duty do not skew the results. Officers who've been shot at in the line of duty show greater support for concealed carry permits. Maybe, they sympathize with their citizen counterpart victims and want them to be able to fight back.

\section{OFFICERS WHO'VE FACED DEADLY FORCE AND THEIR OPINION ON LICENSING HANDGUNS.}

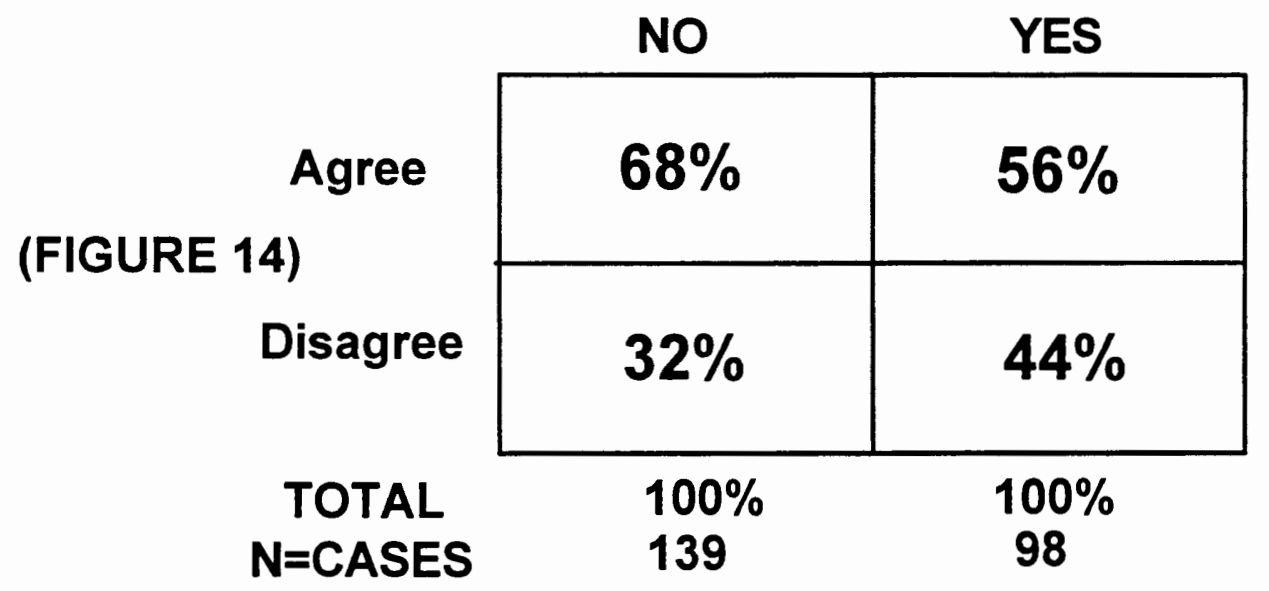

The next set of issues are more restrictive concerning the sale and possession of handguns to the public by federal firearm dealers. If hypothesis 4 holds true, one could say that officers who have encountered deadly would show more support. In regards to licensing handgun owners (Figure 14), the opposite once again is true. Out of the 98 officers who've been exposed to deadly force, $26 \%$ of the cases strongly support licensing compared to the $28 \%$ of officers not exposed to deadly force. When the agree data is included, $56 \%$ of those officers who've been exposed to deadly force support licensing. However, non-deadly force officers show 
greater support with $68 \%$ of the cases supporting licensing. One would think the opposite would occur. One would think that officers shot at in the line of duty would be more supportive of restrictive handgun laws.

The present researcher with the help of past research can only conclude that those criminals who shoot at officers do not legally own their handguns. Therefore, those officers exposed to deadly force might feel less compelled to restrict handguns to the law abiding to defend themselves. Nonetheless, since officers who've been exposed to deadly force show less support for gun control than their non-deadly force counterparts, the present researchers hypothesis 4 has been disproved.

OFFICERS WHO'VE FACED DEADLY FORCE AND THEIR OPINION ON REGISTRATING HANDGUNS .

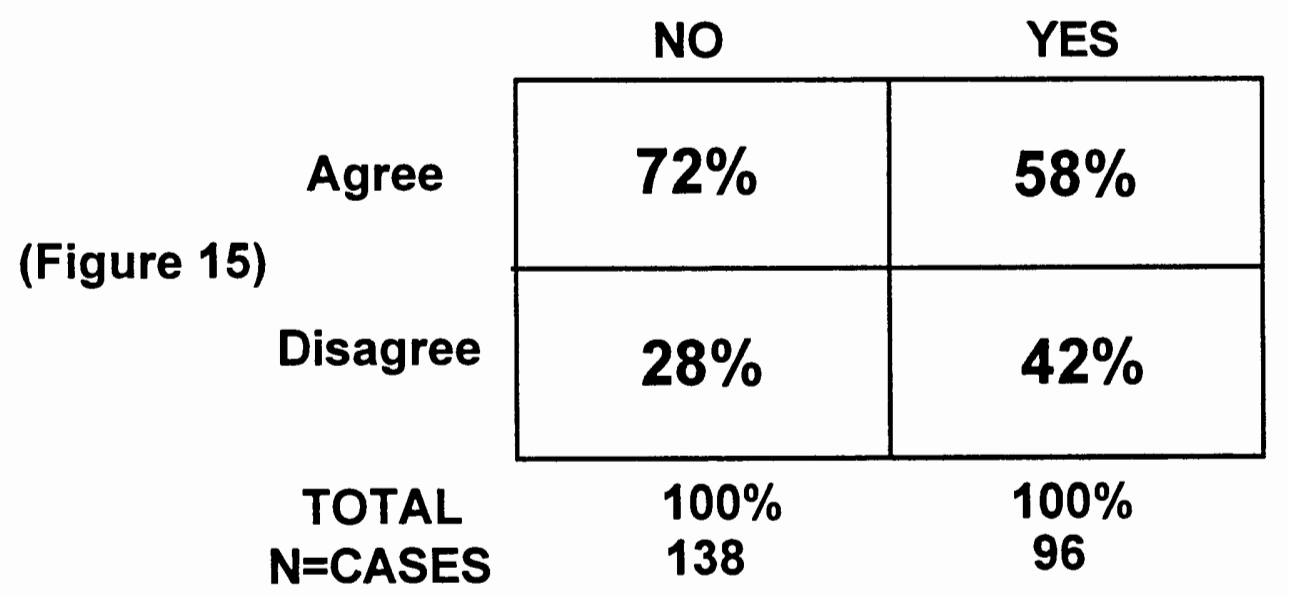

When addressing the issue of registrating handgun owners and handguns, both deadly force and non-deadly force officers show slightly different attitudes (Figure 15). One would think deadly force officers would show stronger support for 
registration? However, the distinction between deadly force and non-deadly force officers with regards to registration is quite the opposite. Out of the 96 officers who've been exposed to deadly force, $32 \%$ strongly support registration compared to $43 \%$ of nondeadly force officers. When the agree data is included, $58 \%$ of the officers exposed to deadly force support registration compared to a greater $72 \%$ of the non-deadly force officers. Once again nondeadly force officers show more support for registration than their deadly force counterparts disproving hypothesis 4 .

Lastly, in regards to prohibition, there is no distinction between deadly force officers and non-deadly force officers. Both tend to show a disagreement with the premise of prohibiting citizens from owning handguns. Out of the 98 officers who've been exposed to deadly force, $63 \%$ strongly disagree with the premise of prohibition. Officers who've not been exposed to deadly force concur with $59 \%$ strongly disagreeing with the premise of prohibition. When the agree data is included, $91 \%$ of those officers exposed to deadly force disagree with prohibition compared to $92 \%$ of non-deadly force. By and large, deadly force toward officers does not skew ones opinions toward gun control. It is apparent in the present study that officers who have been shot at in the line of duty do not exhibit stronger support for restricting public access to handguns. 


\section{CONCLUSIONS}

The intent of this study was to bring the public and private sector up to date on the attitudes of the rank and file police community on the control of firearms. The present researcher feels this issue is significant for these officers have daily contact with the citizenry. The rank and file with their concerns and attitudes should be the main concern of higher administrators, not political agendas. With these aforementioned attitudes uncovered, safety precaution policies involving patrol officers who come into contact with the public can be developed. There can then be a balance between citizens rights and officer safety. This latter issue can be scene in the present Oregon legislator in 1997. House Bill 2433 and House Bill 2432 are two new attempts by the District Attorney Association working with police administrators to expand the inquiry of peace officer powers when an officer has made a traffic stop (NE Portland Lieutenant, 1997). The bills would allow officers when making a traffic stop to make a reasonable inquiry as to the presence of weapons and drugs to ensure the officers' safety. The term reasonable allows for much discretion and is seen as an unleashing of police harassment for the law abiding gun owner. Police administrators see the measure as protecting the officer from the criminal element.

The past literature and the present study show that rank and file vary as to their intensity for support of waiting periods, safety courses, criminal background checks, licensing, registration, ect... 
However, $75 \%$ of the cases favor citizens carrying concealed handguns. Lastly, one thing is consistent in the past and present, police officers do not want handgun or firearm prohibition regardless of higher administrator claims.

Next, when the present researcher compared age to attitudes toward the control of guns, there was no overall distinction amongst the old and the young toward criminal background investigations, waiting periods, safety training, concealed carry permits and prohibition. With regards to licensing handgun owners, younger officers are more likely to support licensing handgun owners compared to their older counterparts. The same is true for registrating handgun owners. The older the officer the less likely the officers will support licensing and registration.

The present researcher then compared personal firearm ownership amongst officers and their attitudes toward the control of guns. Officers who owned personal firearms other than their duty weapon did not have any significant distinction from their non-owner counterparts. Both parties supported background investigations, waiting periods, safety training, and concealed carry permits. Officers who did own personal firearms were not overwhelmingly in favor of licensing and registration as previous issues. These results were not as significant as Siwik (1984) but do slightly support the trend in the literature that officers who do own personal firearms disfavor licensing and registration. Lastly, officers who did own personal firearms did show overwhelming 
opposition to prohibition as did their non-firearm owner counterparts.

Next, when officers are broken up into gender there is no distinction when looking at background investigations, waiting periods, and safety training. In fact, women were more decisive on the previous issues than their male counterparts. When addressing concealed carry permits both supported the idea. The main distinctions appear amongst gender when looking at licensing and registration. Women were more likely to support licensing and registration then their male counterparts. One could conclude that this is due to the victimization by crime and possibly by society. When addressing prohibition, males disfavor prohibition more so than their female counterparts. One could conclude that firearms are inherent more in the male subculture of hunting or father/son relations than their female counterparts.

Lastly, how does officer attitudes toward the control of guns differ when confronted with deadly force. As with previous issues, there was no difference amongst non-deadly force and deadly force officers when addressing background investigations, waiting periods, safety training, concealed carry permits, and prohibition. There is some distinction when addressing licensing and more distinction when addressing registration. Officers who've been exposed to deadly force were less likely to support either licensing or registration. 
As with Norman et al (1983), Siwik et al. (1984) ect..., there was no overwhelming surprising trends when addressing attitudes of the rank and file toward waiting periods, safety training, prohibition, ect... There was varying results when the present researcher addressed licensing and registration. However, the present researcher did find that the rank and file do support the issuing of concealed carry permits as in hypothesis 1 and the involvement of officers in the training of perspective buyers. If policy makers make use of the above results, police-citizen relations can be strengthened. The citizen gun buyer and owner will lessen his/her fear that the police want to take away their guns. 


\section{BIBLIOGRAPHY}

\section{Law Enforcement on Gun Control}

(1)"D.C. POLICE URGE GUN CONTROL NATIONWIDE" by Martin Berg, Los Angeles Daily Journal Feb. 231988 Vol. 101, No. 38 P5.

(2)"EXPLORATORY INVESTIGATION OF POLICE ATTITUDES TOWARD VIOLENCE" by Roy O. Walker, Journal of Police Science and

Administration Vol. 10, No. 11982 P93.

(3)"Facing the Gun: The Firearms Threat to Police Officers" by Robert Little and Max Boylen, Iournal of Police Science and Administration Vol. 17, No. 11990 P49.

(4)"An Analysis of Law Enforcement Officer Attitudes Toward the control of Handguns" by Michael D. Norman and Thomas McAninch, Lournal of Police Science and Administration Vol. 11, No. 31983 P275.

(5)"Law Enforcement Attitudes on Handgun Control" by Robert A. Siwik and William R, Blount, Journal of Police Science and Administration Vol. 12, No. 21984 P157.

(6)"POLICE OFFICERS ON GUN CONTROL", Criminal Justice Newsletter Vol. 14, No. 9 April 25, 1983 P7.

(7)"MAJOR POLICE GROUPS ATTACK NRA OVER GUN DECONTROL BILL", Criminal Justice Newsletter Vol. 17, No. 7 April 1, 1986 P1.

(8)"LEAA Police Officer Addresses School Group on Gun Control: Teacher 'Visibly Irritated'" by Robert Krauss, The LEAA Advocate (Law

Enforcement Alliance of America) Vol. 3, No. 3\&4 Fall-Winter 1994 P58.

(9)"FOP Leadership Reveals Total Support For Gun Control: FOP Member Asks LEAA Members to Respond" by Scott Wagner, The LEAA Advocate Vol. 3, No. 1 Winter 1994 P25.

(10)"Police Officers Forced to Lobby For Gun Ban: LEAA Member, Police Officer Both Sue Chief of Police" by James J. Fotis, The LEAA Advocate Vol. 3, No. 3\&4 Fall-Winter 1994 P17.

(11)"Gun Buy Back Programs Deceive The Public: 'Funds for Felons' Alternative Proposed by Deputy Chief Joseph Constance, The LEAA Advocate Vol. 3, No. 2 Spring 1994 P26. 
(12) "Officers Convicted of Domestic Violence Must Turn in Weapons", by Mark Nichols, American Police Beat Volume 4, Number 1 Jan/Feb 1997

State Case Law \& National Case Law Relating to Firearms and the Duty of the Police to Protect the Individual

(13)"1989 Oregon Gun Control Legislation" by Rhonda Canby, Willamette Law Review Vol. 26:2 Spring 1990 P565.

(14)"Domestic Violence: When Do Police Have a Constitutional Duty to Protect?" by Daniel L. Schofield, S.J.D., FBI Law Enforcement Bulletin January, 1991 P27.

(15) STATE OF OREGON v. MICHAEL EDWARD BLOCKER 291 Or 255 (1981) P255.

(17) STATE OF OREGON v. RANDY KESSLER 289 Or 359 (1980) P359.

(18) Joshua DeSHANEY v. WINNEBAGO COUNTY DEPARTMENT OF SOCIAL SERVICES, et al. SUPREME COURT REPORTER 489 U.S. 189, 103 L.Ed.2d249 (1989) P998.

(19)"Police Assurances of Protection Did Not Create Special Duty To Investigate Or Protect", Hawkeye Bank \& Trust Co. v. Spencer 487 N.W. 2d 94 (Iowa App. 1992), Police Liability Review Vol. 5, No. 1 (3-1993) P28.

(20)"Court Applies Kansas Law to Conduct of Missouri Officer Finding Police Have No Duty to Protect Citizens From Criminal Conduct", Taylor v. Phelan 799 F.Supp. 1095 (D.Kan.1992), Police Liability Review Vol. 5, No. 1 (3-1993) P23.

(21)"FROM THE FEDERAL DISTRICT COURTS: Police Had No Duty To Protect Plaintiff From Domestic Violence", Siddle v. City of Cambridge, Ohio 761 F.Supp. 503 (S.D.Ohio 1991), Police Liability Review Vol. 3, No. 4 (Winter 1991) P20.

(22) EVERTON v. WILLARD 468 So.2d 936 (Fla. 1985), 468 SOUTHERN REPORTER, 2d SERIES P937.

(23)WARRAN v. DISTRICT OF COLUMBIA D.C. App., 444 A.2d 1 (1981), 444 ATLANTIC REPORTER, 2d SERIES, P1. 
(24) WEINER v. METROPOLITAN TRANSP. AUTHORITY N.Y.,433

N.E.2d 124, 433 NORTH EASTERN REPORTER, 2d SERIES, P125.

\section{Oregon Statutes relating to Possession of Firearms}

(25) Constitution of Oregon Article 1 Section 27 (pg.1002)

(26) Public Order Offenses (Issuance of Concealed Handgun License) ORS 166.291-166.300, Oregon Criminal Code 1993-16-117

\section{Concealed Carry Licenses as Crime Deterrent}

(27) Point Blank: Guns and Violence in America, by Gary Kleck School of Criminology and Criminal Justice Florida State University Tallahassee, Florida 32312

(28)"Firearms and Self-Defense by David McDowall. THE ANNALS: of The American Academy of Political and Social Science Vol. 539, May 1995 P130.

(29)"Crime, Deterrence, and Right-to-Carry Concealed Handguns" by John R. Lott, Jr. and David B. Mustard July 26,1996 at the University of Chicago. To be printed in the Journal of Legal Studies January 1997.

(30)"Measuring Protective Handgun Ownership" by Liz Marie marciniak and Colin Loftin at the University of Maryland. Criminology Vol. 29, No. 3 1991 P531.

(31)"General Deterrence Through Civilian Gun Ownership: An Evaluation of the Quasi-Experimental Evidence" by David McDowall University of Maryland, Alan J. Lizotte University of New York at Albany, and Brian Wiersema University of Maryland. Criminology Vol. 29, No. 41991 P541.

(32)"Did gun permit holder in Texas take the law into his own hands?" AP, Statesman Journal, Salem Ore., Saturday, February 24, 1996 Page 3A

(33)"Valley suburbs packing concealed weapons" by Judy Nichols and Charles Kelly The Arizona Republic Sunday, March 17, 1996 106th year, No. 308

(34)"THE OLD EQUALIZER" by Daniel Seligman Fortune December 27 1993 Vol. 238, No. 16 pg. 141 
(35) "Motivations for Gun Possession and Carrying Among Serious Juvenile Offenders", by Joseph F. Sheley and James D. Wright Behavior Sciences and the Law, Volume 11, pg. 375-388 1993

(36) "Concealed Carry Study" by Robert W. Lee The New American Septermber 301996

(37) "Woman who killed burglar not indicted" by Rick Bella The Oregonian February 251994

(38) "Homicide rate stable since 30's study shows" by Rachel L. Jones The Oregonian Thursday, February 21995

(39) "Violent crime down 12.4\%: Biggest drop seen in suburbs", by Haya El Nassar USA Today Monday, April 14, 1997 


\section{APPENDIX A: QUESTIONAIRE}

Case\#

My name is Andrew Schneiderman and I'm conducting a survey concerning the attitudes of police officers toward concealed hangun permits and gun control in general. This shall only take a few minutes of your time.

1. Current Oregon gun laws prevent gun violence.

\begin{tabular}{|c|c|c|c|c|}
\hline $\begin{array}{l}\text { Strongly } \\
\text { Agree } \\
\text { ( ) }\end{array}$ & Agree & $\begin{array}{c}\text { Disagree } \\
\text { ( ) }\end{array}$ & $\begin{array}{l}\text { Strongly } \\
\text { Disagree } \\
\text { ( ) }\end{array}$ & $\begin{array}{c}\text { No } \\
\text { Opinion } \\
\text { ( ) }\end{array}$ \\
\hline ( ) & ( ) & ( ) & ( ) & ( ) \\
\hline () & ( ) & ( ) & ( ) & () \\
\hline
\end{tabular}

3. Current Oregon gun laws prevent the shooting of police officers.

4. I favor criminal background investigations before a person can buy a handgun.

5. I favor a waiting period before a person can buy a handgun.

( ) ( ) ( ) ( ) ( )

6. I favor mandatory safety courses before a person can buy a handgun.

7. I favor allowing qualified persons carry a concealed handgun.

8. I favor licensing those persons who want to buy a handgun.

9. I favor the registration of all handguns.

10. I favor making the ownership of a handgun illegal except for police or the military.

(

( )

( )

( )

( )

11. I favor police involvment in training those people who want concealed carry permits.

( ) () () () ()

12. Do you own a firearm other than your duty weapon?

( )

( )

( )

( )

13. Do you hunt or shoot recreationally?

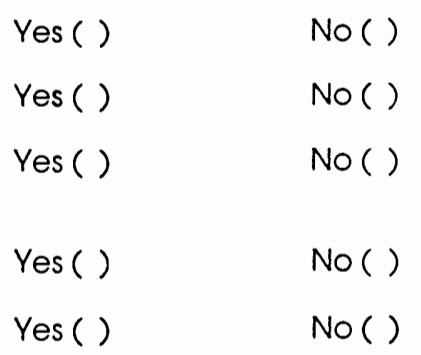

16. Have you ever been shot or shot at?

14. Do you shoot on a regular basis other than qualiying with your duty handgun?

15. Have you ever fired your weapon in the line of duty?

17. How many years have you been employed as a policer officer?

18. Respondent Age:

19. RespondentGender:

Male ( ) Female ( )

Thank you for your cooperation and time. 


\section{APPENDIX B: INFORMED CONSENT FORM}

\section{Informed Consent Form}

I as a police officer understand that the study involves obtaining rank and file police officer attitudes toward the 1989 Oregon Concealed Carry Handgun Law and gun control in general. Andrew Schneiderman has informed me that the purpose of this study is to collect responses to the enclosed questionnaire for his Masters Thesis on the above subject. He has also informed me that the available information may be utilized in the future to develop officer-citizen safety measures for those citizens legally carrying concealed handguns. Andrew Schneiderman has also offered to answer any questions as to what is expected of me. The researcher has informed me that participation in this study is voluntary. No personal names or addresses will be requested of me and no connection will be made between questionnaires and participating officers. I understand that I do not have to participate in this study. Non participation will not increase risks to my employment status or to the outcome of the researchers work. Lastly, I have also been made aware that the questionnaires will be destroyed after the data is compiled. 


\section{APPENDIX C: PUBLIC ORDER OFFENSE 166.292}

\section{APPLICATION FOR LICENSE TO CARRY CONCEALED HANDGUN}

I hereby declare as follows:

I am a citizen of the United States or a legal resident alien who can document continuous residency in the county for at least six months and have declared in writing to the Immigration and Naturalization Service my intention to become a citizen and can present proof of the written declaration to the sheriff at the time of this application. I $\mathrm{am}$ at least 21 years of age. I have been discharged from the jurisdiction of the juvenile court for more than four years if, while a minor, I was found to be within the jurisdiction of the juvenile court for having committed an act which, if committed by an adult, would constitute a felony or a misdemeanor involving violence, as defined in ORS 166.470. I have never been convicted of a felony or found guilty, except for insanity under ORS 161.295, of a felony in the State of Oregon or elsewhere. I have not, within the last four years, been convicted of a mis. demeanor or found guilty, except for insanity under ORS 161.295, of a misdemeanor. There are no outstanding warrants for my arrest and I am not free on any form of pretrial release. I have not been committed to the Mental Health and Developmental Disability Services Division under ORS 426.130, nor have I been found mentally ill and presently subject to an order prohibiting me from purchasing or possessing a firearm because of mental illness. If any of the previous conditions do apply to me, I have been granted relief or wish to petition for relief from the disability under ORS 166.274 or 166.293 or 18 U.S.C. $\$ 925(\mathrm{c})$ or have had the records expunged. I understand I will be fingerprinted and photographed.

Age

Place of birth

Date of birth

Social Security Number

(Disclosure of your social security account number is voluntary. Solicitation of the number is authorized under ORS 166.420 . It will be used only as a means of identification.)

Proof of identification (Two pieces of current identification are required, one of which must bear a photograph of the applicant. Type of identification and number on identification to be filled in by sheriff)

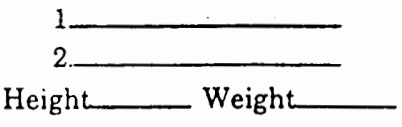

Current address
(List residence addresses for the past three years on back)

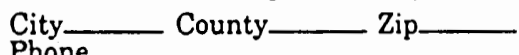

Phone

$I$ have read the entire text of this application, and the statements therein are correct and true. (Making false statements on this application is a misdemeanor.)

(Signature of Applicant)

Character references.

\begin{tabular}{l} 
Name Address \\
\hline \multicolumn{1}{c}{ Name Address } \\
Approved Disapproved - by- \\
Competence with handgun demonstrated \\
by_ (to be filled in by sheriff) \\
Date_ Fee Paid. \\
License No.
\end{tabular}

(5)(a) Fees for concealed handgun li censes are:

(A) $\$ 15$ to the Department of State Police for conducting the fingerprint check of the applicant.

(B) $\$ 50$ to the sheriff for the issuance or renewal of a concealed handgun license.

(C) $\$ 15$ to the sheriff for the duplication of a license because of loss or change of address.

(b) The sheriff may enter into an agreement with the Department of Transportation to produce the concealed handgun license.

(6) No civil or criminal liability shall attach to the sheriff or any authorized representative engaged in the receipt and review of, or an investigation connected with, any application for, or in the issuance, denial or revocation of, any license under ORS 166.291 to 166.295 as a result of the lawful perform. ance of duties under those sections.

(7) Immediately upon acceptance of an application for a concealed handgun license the sheriff shall enter the applicant's name into the Law Enforcement Data System indi. cating that the person is an applicant for a concealed handgun license or is a license holder.

(8) The county sheriff may waive the residency requirement in subsection $(1)(c)$ of this section for a resident of a contiguous state who has a compelling business interest or other legitimate demonstrated need. (1989 c839 88 (166.291 to 166.293 enacted in lieu of 166.290 ): 1991 c.67 \$38; 1993 c.732 \$2; 1993 c.735 \$4]

166292 Procedure for issuing; form of license; duration. (1) If the application for 
the license is approved, the sheriff shall issue and mail or otherwise deliver to the applicant at the address shown on the application, within 45 days of the application, a wallet sized license bearing the photograph of the licensee. The license must be signed by the licensee and carried whenever the licensee carries a concealed handgun.

(2) Failure of a person who carries a concealed handgun also to carry a concealed handgun license is prima facie evidence that the person does not have such a license.

(3) Licenses for concealed handguns shall be uniform throughout the state in substantially the following form:

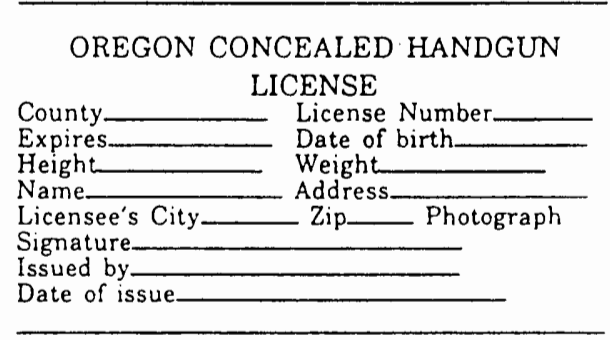

(4) An Oregon concealed handgun license issued under $O R S 166.291$ and this section unless revoked under ORS 166.293, is valid for a period of four years from the date on which it is issued.

(5) The sheriff shall keep a record of each license issued under ORS 166.291 and this section, or renewed pursuant to ORS 166.295

(6) When a sheriff issues a concealed handgun license under this section, the sheriff shall provide the licensee with a list of those places where carrying concealed handguns is prohibited or restricted by state or federal law. [1989 c.839 \$9 (166.291 to $166.293 \mathrm{en}$. acted in lieu of 166.290); 1993 c.625 \$5; 1993 c.693 \$2; 1993 c.735 §5]

166.293 Denial or revocation of license; review. (1) If the application for the concealed handgun license is denied, the sheriff shall set forth in writing the reasons for the denial. The denial shall be sent to the applicant by certified mail, restricted delivery, within 45 days after the application was made. If no decision is issued within 45 days, the person may seek review under the procedures in subsection (5) of this section.

(2) Notwithstanding ORS 166.291 (1), and subject to review as provided in subsection (5) of this section, a sheriff may deny a concealed handgun license if the sheriff has reasonable grounds to believe that the applicant has been or is reasonably likely to be a danger to self or others, or to the community at large, as a result of the applicant's mental or psychological state, as demonstrated by past pattern of behavior or participation in incidents involving unlawful violence or threats of unlawful violence.

(3) Any act or condition that would prevent the issuance of a license under ORS 166.291 to 166.293 shall be cause for revoking a concealed handgun license. A sheriff may revoke a license by serving upon the licensee a notice of revocation. The notice must contain the grounds for the revocation and must be served either personally or by certified mail, restricted delivery. The notice and return of service shall be included in the file of the licensee. The revocation is effective upon the licensee's receipt of the notice.

(4) Any peace officer or corrections officer may seize a concealed handoun license and return it to the issuing sheriff when the license is held by a person who has been ar. rested or cited for a crime that can or would otherwise disqualify the person from being issued a concealed handgun license. The issuing sheriff shall hold the license for 30 days. If the person is not charged with a crime within the 30 days, the sheriff shall return the license unless the sheriff revokes the license as provided in subsection (3) of this section.

(5) A person denied a concealed handgun license or whose license is revoked or not renewed under ORS 166.291 to 166.295 may petition the district court in the petitioner's county of residence or, if there is no district court, the circuit court to review the denial nonrenewal or revocation. The petition must be filed within 30 days after the receipt of the notice of denial or revocation.

(6) The judgment affirming or overturning the sheriffs decision shall be based solely on whether the petitioner meets the criteria that are used for issuance of the license under ORS 166.291 to 166.293. Whenever the petitioner has been previously sentenced for a crime under ORS 161.610 or for a crime of violence for which the person could have re ceived a sentence of more than 10 years, the court shall only grant relief if the court finds that relief should be granted in the interest of justice.

(7) Notwithstanding the provisions of ORS 9.320 , a corporation, the state or any city, county, district or other political subdivision or public corporation in this state, without appearance by attorney, may appear as a party to an action under this section.

(8) Petitions filed under this section shall be heard and disposed of within 15 judicial days of filing or as soon as practicable thereafter.

(9) Filing fees for actions shall be as for any civil action filed in the court. If the pe- 
titioner prevails, the amount of the filing fee shall be paid by the respondent to the petitioner and may be incorporated into the court order.

(10) Initial appeals of petitions shall be heard de novo. Appeals from district cnurt shall go to circuit court. ..:

(11) Any party to a judgment under this section may appeal to the Court of Appeals in the same manner as for any other civil action.

(12) If the governmental entity files an appeal under this section and does not prevail, it shall be ordered to pay the attorney fees for the prevailing party. (1989 c.839 \$9a (166.291 to 166.293 enacted in lieu of 166.290); 1993 c.735 \$6]

166.295 Renewal of license. (1)(a) A concealed handgun license is renewable by repeating the procedures set out in ORS 166.291 and 166.292, except for the requirement to submit fingerprints and provide character references.

(b) An otherwise expired concealed hand. gun license continues to be valid for up to 45 days after the licensee applies for renewal if:

(A) The licensee applies for renewal before the original license expires;

(B) The licensee has proof of the application for renewal; and

(C) The application for renewal has not been denied.

(2) If a licensee changes residence, the licensee shall report the change of address and the sheriff shall issue a new license as a duplication for a change of address. The license shall expire upon the same date as would the original. [1989 c.839 \$10, 1993 c.735 \$7]

166.297 Annual report regarding revocation of licenses. (1) The sheriff of a county shall submit annually to the Department of State Police a report containing the number of concealed handgun licenses revoked during the reporting period and the reasons for the revocations.

(2) The Department of State Police shall compile the reports submitted under subsection (1) of this section and shall submit the compilation to the Legislative Assembly biennially. [1993 c.735 \$13]

166.300 Killing another as cause for loss of right to bear arms. (1) Any person who has committed, with firearms of any kind or description, murder in any degree, or manslaughter, either voluntary or involuntary, or who in a careless or reckless manner, kills or injures another with firearms, and who, at any time after committing murder or manslaughter or after said careless or reckless killing or injury of another, carries or bears firearms of any kind or description within this state, shall be punished upon conviction by a fine of not more than $\$ 500$, or by imprisonment in the county jail not to exceed one year, or both.

(2) Subsection (1) of this section does not deprive the people of this state of the right to bear arms for the defense of themselves and the state, and does not apply to any peace officer in the discharge of official duties or to a member of any regularly constituted military organization while on duty with such military organization.

(3) Justices of the peace, district courts, county courts and all other courts having jurisdiction as justices of the peace, shall have concurrent jurisdiction with the circuit courts of all prosecutions under subsection (1) of this section.

Noto: Soe note under 166.180 .

168.910 [Repealed by 1985 c.709 \$4]

166.320 Setting springgun or setgun. (1) Any person who places or sets any loaded springgun, setgun, or any gun, firearm or other device of any kind designed for containing or firing explosives, in any place where it may be fired, exploded or discharged by the contact of any person or animal with any string, wire, rod, stick, spring or other contrivance affixed to or connected with it, or with its trigger, shall be punished upon conviction by a fine of not less than $\$ 100$ nor more than $\$ 500$, or by imprisonment in the county jail for not less than 30 days nor more than six months, or both.

(2) Subsection (1) of this section does not apply to any loaded springgun, setgun, firearm or other device placed for the pur. pose of destroying gophers, moles or other burrowing rodents, and does not prevent the use of a coyote getter by employees of county, state or federal governments engaged in cooperative predatory animal control work.

Note: See note under 166.180

166.330 Use of firearms with other than incombustible gun wadding. Any person who uses in any firearms discharged on lands within this state, not owned by the person, anything other than incombustible gun wadding, shall be punished upon conviction by a fine of not less than $\$ 5$ nor more than $\$ 100$, or by imprisonment in the county jail for not less than two days nor more than 60 days.

Note: See note under 166.180

$166 \$ 40$ [1965 c.20 \$\$2,3; 1969 c.351 \$1; repealed by 1981 c.41 \&3]

166.350 Unlawful possession of armor piercing ammunition. (1) A person commits 